\title{
THE DIPLOID CHROMOSOME COMPLEXES OF THE PIG (SUS SCROFA) AND THEIR VARIATIONS
}

\author{
ROBERT T. HANCE \\ Zoological Laboratory, University of Pennsylvania \\ TEN PLATES AND FIVE TEXT HIGURES
}

\section{CONTENTS}

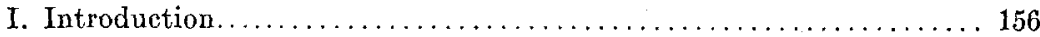

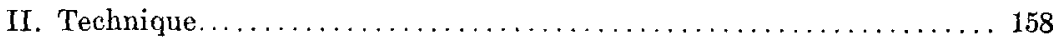

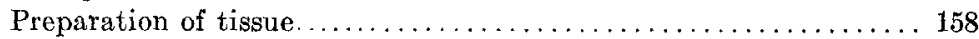

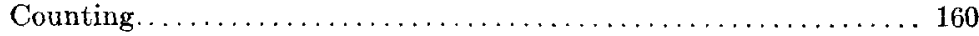

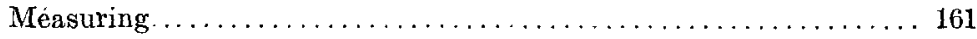

Mechanical aids................................. 161

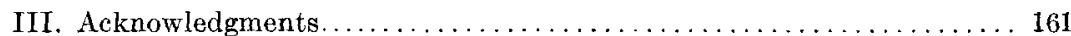

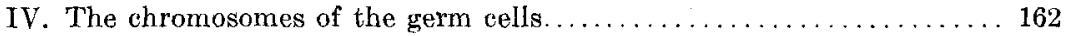

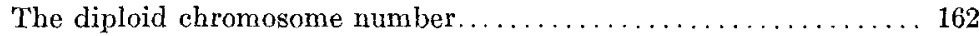

The structure of the chromosomes................... 163

$A$ giant cell ..................................... 164

The reduced number of ehromosomes.................. 164

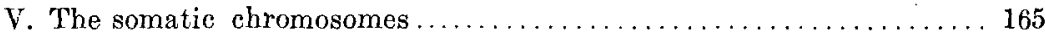

The chromosome number. . . . . . . . . . . . . . . . . 165

The range of number variation in the various tissues......... 166

The chromosome number in uncut membranes............. 167

The behavior of the 'extra' chromosomes................ 168

The cause of the number variation.................. 169

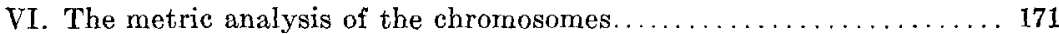

Spermatogonia................................. 172

Total length of the chromosomes................. 172

Pairs and relation of pairs. . . . . . . . . . . . . . . . 172

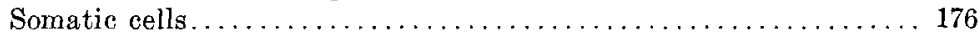

Total length of the chromosomes.................. 177

Total length of the chromosomes in the various tissues....... 178

The length of the chromosome fragments............. 178

Discussion of the results of measuring the chromosomes........ 179

The conditions in Oenothera scintillans............... 179

The conditions in the pig. . . . . . . . . . . . . . . . . . . . 180

A comparison of the conditions in the two forms $\ldots \ldots \ldots \ldots \ldots 181$

The point of fragmentation....................... 183 
VII. Discussion.......................................... 184

The work of other mammalian cytologists..............., 184

Reported cases of fragmentation...................... 190

The metrical study of chromosomes..................... 192

Chromosomes in development....................... 193

The individuality of the chromosomes. . . . . . . . . . . . 196

VIII. Summary ...................................... 196

IX. Bibliography ..................................... 199

\section{INTRODUCTION}

The terms spermatogonial and somatic have been frequently used synonymously, with respect to the diploid chromosome number, on evidence considerably more theoretical than direct. As a matter of fact comparatively little work has been done on the body cells, as the germ cells, because of their genetic significance, have, until recently, largely held the interest of cytologists. Important as is the theoretical significance of the chromosomes of the germ cells, it seems to me that the chromosomes of the body are fully as interesting. In the soma, as the various cells differentiate in to the tissues that constitute the mature plant or animal, we can see in operation the chromatin whose maturation phenomena we trace through the reproductive cells. What, we may ask, is the behavior of the chromosomes in development? Are they immutable, or do they undergo change? If changes occur, are they correlated with the character of the tissue in which the variation is found? Also in the event of change what bearing does it have on the theory of the individuality of chromosomes?

Four years ago I selected the pig for studying the problems suggested above. The methods of fixation, then in common use, proved hopeless, as the chromosomes, following the use of the usual fixatives, were clumped together beyond hope of recognition-a condition quite typical of the majority of published figures of mammalian mitoses. My work was consequently delayed until a method was discovered which preserves the chromosomes in a condition comparable to the best cytological preparations. The results obtained with this technique (Hance, '17 b) are considered to be representative of the living structures as 
they compare favorably in every way with those obtained on the grasshoppers, the fixed tissue of which has been compared and checked with studies on living cells. The methods of fixation which have been developed may now be said to place mammalian tissues in the list of workable cytological materials. Probably not the least of the reasons for the few ventures in to the field of somatic cytology has been a scarcity of divisions, but this is an avoidable condition for tissues may be found showing as many mitotic figures as the best testicular material. The difficulty that investigators frequently met with in locating dividing cells in mammalian testes is entirely obviated by securing material from several animals and then selecting for study that animal which is in what I have termed elsewhere, a 'cycle of division.' The cycle holds for both testes and embryo, and I have found it also in plants.

Cytologists, who have studied the cells of the soma, may be be divided into two general groups--those who maintain that the somatic chromosome number is fixed and identical with that of the spermatogonia, and those who believe that it is variable. I believe that it may safely be said that both groups have drawn conclusions from too little evidence and, in some cases at least, this evidence has been obtained from very poor material. This is particularly true of the 'variable chromosome group,' among whom belong those, who, with Della Valle, hold the chromosomes to be unimportant structures and who believe that the supposed variations express and emphasize the lack of chromosome importance. Which of these groups is right will be considered later. Ina recent paper (Hance '18) it has been pointed out that

only when the investigator of somatic chromosomes has a sufficiently large and properly preserved number of somatic figures to study and has subjected the chromosomes to every possible analysis is he justified in taking up the cudgels for or against the theories that have developed around the many excellent studies on germinal complexes. There is a very apparent and regrettable tendency of late on the part of some cytologists to attempt merely to correlate their own findings with those of some classic work on another form, passing, at times, variations that have been found, either because they were thought unimportant, because they were supposedly pathological, or perhaps, 
because they appeared impossible of interpretation. Since the physiological character of the chromosomes are as yet undetermined and since at present our only method of forming a conception of the activities of the chromatic material is through morphological studies in the broadest sense, it scarcely needs to be pointed out that uncritical wotk of the sort discribed is not likely to be productive of results.

It is quite true that when we have determined the behavior of somatic chromosomes we are not a great deal nearer the solution of development for it seems quite evident that the ultimate analysis of this problem must be largely a chemical one. But, since chemical studies of such nature are impossible at present, morphological investigations may indicate the lines which future research may advantageously follow and even may indirectly, through a careful study of the division phenomena in many tissues of a large number of plants and animals, lead to an understanding of the physiology of the cell.

\section{TECHNIQUE}

Preparation of tissue. Probably more inaccuracies in cytological work have resulted from the use of poorly prepared material than in any other way. This is particularly true of mammalian studies, and, with the possible exception of the investigations of Winiwarter, the work of other mammalian cytologists is practically valueless and will have to be carefully repeated. We have definite criteria now with which to judge our preserved material, namely the studies on the living cell (Lewis and Robertson, '16). Consequently the cytologist who attempts to unravel clumped chromosomes and to draw conclusions on the supposition that he knows the chromosomes as they are, not only invites destructive criticism of his work, but adds nothing to our knowledge and wastes our time.

The method that has given excellent results has already been described at length (Hance, '17 b). In brief it is as follows:

1. Obtain fresh specimens from as many different animals as possible so as to be sure of obtaining one or more in a 'cycle of division.' 
2. Place small or finely teased pieces of fresh tissue into cold Flemming's (strong) solution to which a little urea (one-half per cent) has been added. When the bottles of fluid are surrounded with ice the temperature of the fixative is about four degrees Centigrade. Allow the tissue to remain in the fluid twenty to twenty-four hours. (Flemming's weak solution was also used successfully. See below.)

3. Wash in water for about twenty-four hours.

4. Dehydrate by very gradual steps.

5. Clear from 95 per cent alcohol in cedar oil followed by xylol.

6 . Imbed in paraffin.

7. Cut the sections ten micra thick.

8. Bleach the sections for from one to twenty-four hours in peroxide.

9. Stain with iron alum haematoxylin.

This method has never failed to give good results and has been used on over sixty lots of material taken from seven mammalian species. The same results were obtained on testes, ovary and embryo.

I have studied testes obtained at the time of castration from pigs about four or five months old representing three breeds, Berkshire, Jersey red and Poland china. The first two were obtained at Philadelphia and the last from Kentucky. None of the pigs were thoroughbreds, although I was told that the Poland china was 'nearly so,' whatever that may mean. Forty-two embryos of various sizes have been fixed either entire or teased. The fixation in the case of those killed without teasing is as good as in the shredded embryos. Only a few of the specimens from this lot of material have been studied, since it was thought better to initiate this study with thorough observations on a small number of animals. It has been a matter of considerable regret that I have been unable to study any ovarian chromosomes. I recently prepared embryonic ovaries taken from foetuses about half grown, but all the material proved worthless, as the chromosomes were badly clumped. The only explanation I have to offer for this is that the system in the Philadelphia slaughter- 
house in which the pigs were obtained was rather slow and the embryos were probably dead before they reached me.

Since the work on sectioned material was completed I have obtained another lot from Cincinnati. These specimens I preserved both in Flemming's weak and strong solutions to which urea had been added. The fluids were used at a temperature of four degrees Centigrade. The embryos apparently were not in a cycle of division for figures were too few to justify study. The amnion from the same pigs was fixed separately and mounted without sectioning. The amnion is quite thin and gave excellent results with the certainty of uncut cells. The slight shrinkage which occurs during the infiltration of paraffin is avoided and the chromosomes appear slightly larger in the amnionic material and in general, better separated. No differences were noted in the character of the fixation by either killing fluid. Both gave excellent results as may be judged from the photomicrographs, figures $88,89,90$ and 93 . I.cannot say, at present, whether the weak solution will work equally well on thicker tissue. The chief advantage of the weak solution, as far as known now, is one of cost.

\section{Counting and checking}

When as large a number of chromosomes are involved in as small a space as are the chromosomes in the cells of the pig, drawing and counting is not easy, notwithstanding the almost perfect separation of the individual elements. Inaccuracies in drawing were avoided in the following manner: The chromosomes of a cell were carefully drawn on a $3 \times 5$ card and the drawing was then checked with oculars of various powers. The card was then filed away for a time. Later, it was brought out and on it the same set of chromosomes was again drawn. This drawing was checked as in the case of the first. Then the two drawings were compared and the points of difference, should any be found, were decided by comparison with the cell under the microseope. This method saved considerable time and, I believe, gave very accurate results. 


\section{Methods of measuring}

The chromosomes were enlarged with a pantograph six diameters over the original magnification (which was $3400 \times$ ). This not only made easier to measure the chromosomes but gave somewhat more accurate results. Many of the chromosomes are practically straight, so that a rule could be used in measuring. The automatic map measure was employed in obtaining the length of the curved chromosomes. The advantages of this instrument have been described (Hance, '18). It has the disadvantage that millimeters must be estimated. This, I believe, I have been able to do with an error of at the most not more than one or two millimeters. With the large magnification of $20,400 \times$ these results appear to me to be sufficiently accurate.

\section{Mechanical aids}

The automatic tally register has been found a great convenience for counting the chromosomes. It enables the investigator to go from the drawing to the microscope without the necessity of remembering the number that has already been counted. The chromosomes are, of course, checked as counted. Before this device was tried drawings would frequently have to be counted several times to be certain that no error had been made.

An adding machine has been of the greatest assistance in this work as has also a 'Calculex,' or circular slide rule, which was used for determining percentages.

A large number of drawings of mitotic figuras are presented with this paper, partly to counteract the general impression, gained from published mammalian studies, that clear figures are difficult to find, but largely to give a better idea of the appearance and relationship of the chromosomes of the various cells.

\section{ACKNOWLEDGMENTS}

For material I am exceedingly grateful for the courtesies extended me by the Pitmann-Moore Biological Laboratories of Indianapolis, by Mr. Clarence Keen of Kingan and Company, packers, of Indianapolis and by Ir. Reed of the Mulford Biological Farm 
at Glenolden, $\mathrm{Pa}$. It is a pleasure to acknowledge the kindness and the interest of these various persons and their assistance in helping me get the material I needed. Such friendly coöperation between the biological manufacturer, commercial establishment and the theoretical laboratory cannot fail, in the long run, to be productive of results beneficial to all concerned.

The many facilities placed at my disposal by Dr. McClung, and his constant interest and friendly advice and criticism have made my stay at the University of Pennsylvania not only profitable, but very enjoyable, a period always to be remembered with great pleasure.

I feel that a list of acknowledgments would be incomplete if no mention were made of my appreciation of and indebtedness to my mother and father to whose encouragement, constant interest and sympathy I owe so much.

\section{THE CHROMOSOMES OF THE GERM CELLS}

\section{The diploid chromosome number}

Only those cells have been considered in which the chromosomes were well separated (figs. 1 to 20 ) where the count could be made with comparative ease and accuracy. Forty chromosomes have been found constantly in the spermatogonia of the pig. This number has appeared in testicular material from three Berkshires, five Jersey reds and one Poland china, the material being gathered from rather widely separated regions of this country. The drawings in figures 1 to 20 , though selected for flatness to show the full length of the chromosomes are not exceptional as to clearness. The photomicrographs in figures 88 to 99 emphasize the separation and sharp outlines of the chromosomes.

It may occur to the reader that the chromosome number may be influenced by precocious division, since, in the drawings, splits are shown in the chromosomes while they lie in the metaphase plate. With experience the chromosomes which have divided are distinguishable by the difference of level and diameter. Furthermore, the count of forty has been made in cells in pro- 
phase (figs. 1,2 and 3) and also in anaphase (fig. 16). With the counts in these three stages checking, I feel confident of the accuracy of the result.

\section{The structure of the chromosomes}

Figures 1 to 20 show that there is some variation in the width or diameter of individual chromosomes, in any given cell. The difference within the cell is very slight and may be due to the fact that the dye is extracted more rapidly from small than from larger chromosomes. In more heavily stained material this difference is not so obvious (figs. 4 and 5) but exists to some extent. The prophases do not show this variation in diameter. In some of the metaphase chromosomes I am inclimed to believe that the extra width is due to the beginning separation of the chromatids, the split being filled with dye. It will be noticed, however, that the diameter of any one chromosome is the same throughout its length.

The presence at various stages of splits in the chromosomes is so variable that at present definite conclusions cannot be drawn. In material passed through paraffin splits are occasionally visible in a few chromosomes in prophases (fig. 3) and it is not possible to determine whether these are obliterated before metaphase is reached or not. From studies of unsectioned amnion which was much superior to the imbedded material for fine details, it seems certain that all the chromosomes of the prophase are split (fig. 81) and that this condition is maintained through the metaphase. Slight differences in fixation or staining would tend to obliterate these fine separations. A slightly oblique view of the chromosome would also tend to obscire the split.

In recent years the point of spindle fibre attachment has been found important. It is difficult in the material I have of the pig to directly determine this point as the spindles are visible in but very few instances. Indirectly it is possible to obtain some evidence as to the point of fibre attachment from the shape assumed by the chromosomes in anaphase as the form at this time would be dependent upon the point of the chromosome at which 
the pull was applied. In other words, if the spindle fibre is attached to the end of the chromosome or is telomitic (Carothers '17) the daughter chromosomes pass to the poles as rods whereas if the attachment is along the body of the chromosome or is atelomitic then upon separation the daughters approach the poles as $V$ 's with equal or unequal arms depending upon whether the fibre is joined to the exact middle or to one side of the middle of the chromosome. Figure 16 shows rods and V's which have already reached the poles. Figures 84,87 and 88 show rods V's with equal and unequal arms approaching the poles. From the material studied it may be said that the fibre attachment is in some instances telomitic and in others atelomitic. More chromosomes apparently have terminal fibre attachment than subterminal fibre attachments. I cannot present complete evidence as to the constancy of the point of fibre attachment in the pig but the similar form of certain recognizable chromosomes (the longer ones) in various cells would seem to indicate a permanency of the location of fibre attachment.

\section{A giant cell}

Figure 14 is a drawing of the chromosomes of a giant cell found among the spermatogonia. The chromosomes at the right hand end, as the cell has been placed on the plate, are somewhat crowded and indistinct, but there are at least as many chromosomes as are figured. The number is seventy-four, which is just six less than double the normal spermatogonial number. Since the chromosomes do not appear smaller than those in the normal cells and the chromosome number is nearly double that usually found, it is believed that this cell has arisen, either through the fusion of two spermatogonia or because separation of the daughter cells failed to take place after the chromosomes had divided.

\section{The rccuced number of chromosomes}

Although no particular study has been made of the spermatocyte chromosomes, I have included two very clear figures at the end of plate 2 . Both of these show twenty chromosomes. Those 
familiar with the characteristic shape of the first spermatocyte chromosomes, as found in the grasshoppers, some of the bugs and other forms, will recognize similar forms here. These forms were not shown in the previous study of the spermatogenesis of the pig (Wodsedalek, '13).

\section{THE SOMATIC CHROMOSOMES}

The present report must necessarily be preliminary in nature and intended rather to point out certain conditions that exist, than to offer a final solution of the problem. With this in mind, two embryos were selected for the study of the chromosome conditions in the body - one embryo of eight, the other of fifteen millimeters. The smaller embryo was fixed entire, while the larger one was teased. The teasing was not sufficient to interfere greatly with the recognition of the various tissues. The fixation in both was excellent, as may be judged from the drawings, and was fully as good as was obtained in the germ cells. Only those cells were selected for drawing which were clearly uncut and in which the chromosomes were well separated and distinct. Small cells possessing a large number of chromosomes, may, even in the most perfectly preserved material, occasionally present one of two places where the number of chromosomes involved is uncertain. This will be spoken of later.

\section{The chromosome number}

It was soon found that the somatic chromosome number was not constant. The variation ranged from forty to fifty-seven, and one cell was found in which at least seventy-four chromatin bodies were counted. Ninety-one cells were counted. (See page 167.) Drawings of the various types of cells found in the embryo are given in figures 23 to 88 . Although, at first, the greatest variation was thought to be confined to the blood, as more tissues were studied, it was found that the blood wás not an exception to the rule and that a similar range of numbers was present in each tissue in which a number of active cells were found. The following table gives in detail the distribution of the variations in the thirteen tissues studied. 
Table of chromosome numbers in the various tissues studied

The figures at the top of each column refer to the number of chromosomes and the figures in the columns indicate the number of examples found

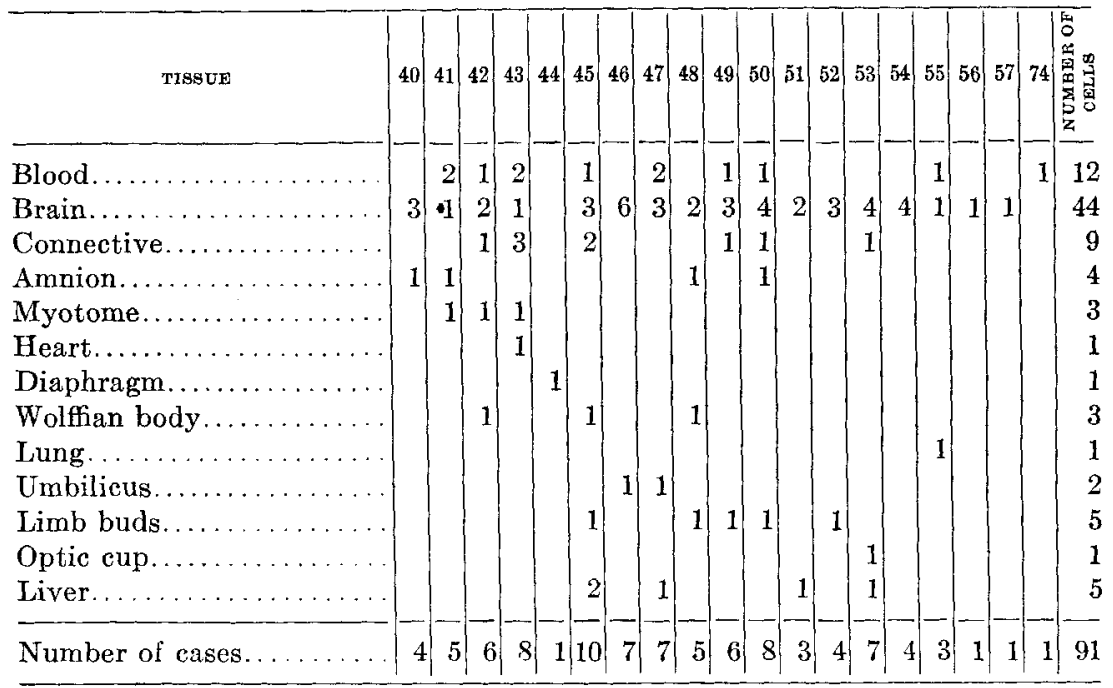

Text figure 1 illustrates graphically some of the conditions given in the above table. On this chart no one type or group of cells appears to be predominant. It seems very probable that when a larger number of cells are studied, this curve will 'straighten' out, showing approximately the same number of cells falling in the various classes.

Had the variation in number been but one or two it might have been attributed to errors in observation and drawing because of the many chromosomes in the cells. But the numbers ranged from forty to fifty-seven, which excludes the possibility of error from this source. An error of one or two chromosomes might well be made but, considering the excellence of the preparations and the care taken in checking the drawings, not one of seventeen. In recording the chromosomes my constant effort was to underestimate rather than to overestimate the number. It was frequently difficult to determine whether the chromatin body under examination was really single or composed of two parts. In all such cases, except where I was finally able to determine defi- 
nitely, I have counted the doubtful element as one rather than two. This difficulty was encountered, particularly in cells possessing fifty or more chromosomes and, in many instances, cells which I have placed in, for example, the fifty chromosome class may well have fifty-one, fifty-two or fifty-three chromosomes. There are certainly, however, at least as many chromosomes in a cell as are indicated by my numbers and my drawings.

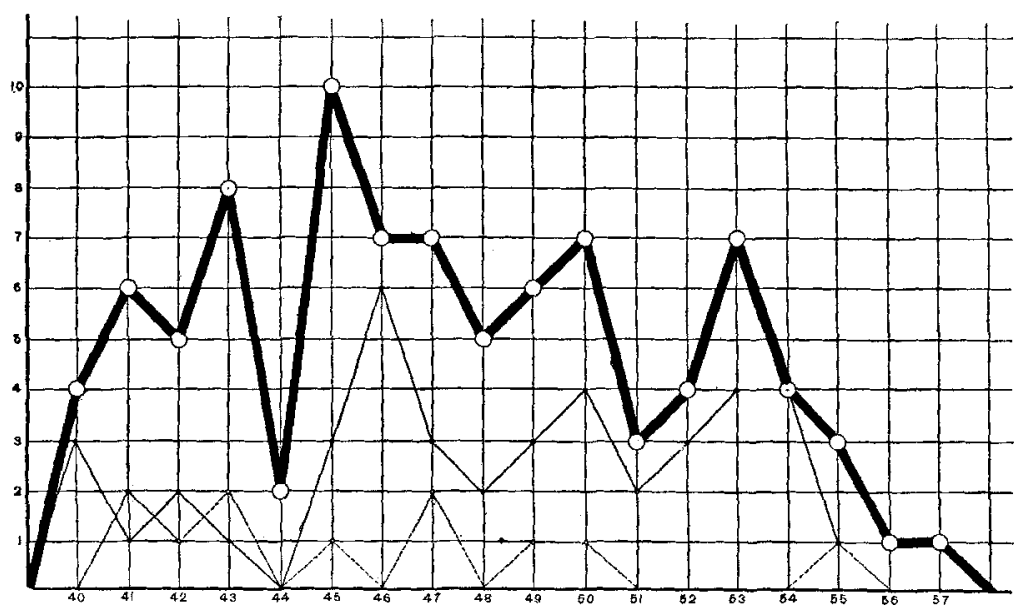

Text fig. 1 A frequency curve (heavy band) showing the group distribution of cells possessing various numbers of ehromosomes as found in ninety-two somatic cells of the pig. The thin solid line represents the range and distribution of variation for cells of the brain and the broken line does the same for the blood. None of these curves appear to have a definite mode. The number of chromosomes are listed on the base line while the frequencies are recorded on the axis of ordinates.

\section{The chromosome number in uncut membranes}

Since the main work of this study was completed I have obtained fresh material from Cincinnati. The amnion of embryo pigs (18 to $20 \mathrm{~mm}$.) was prepared as described (page 160) and was found exceedingly favorable for study. The thickness varies but in the portions observed it was seldom more than three cells thick and frequently the membrane seemed to be composed of a single layer. The certa'nty that the cells were uncut made the 
material excellent for checking the results obtained on the earlier sectioned embryos. The clearness of the figures in these membranes is evident from figures 81 to 85 and (phqtomicrographs) 89 to 93 and 95 .

Nearly all the cells studied were in prophase lending further support to the idea of a 'cycle of division' (page 157). Twentynine cells have been drawn and counted and the range of number is the same as reported for the rest of the soma. The twentynine cells fall into the following groups:

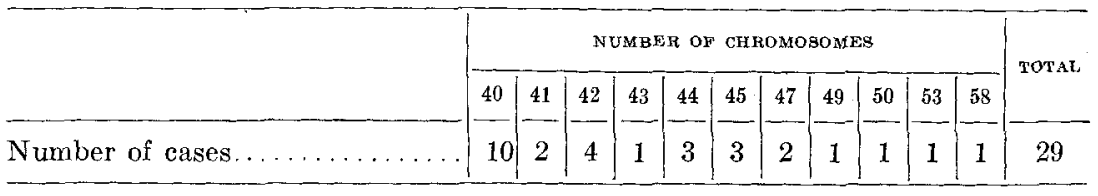

There are more cells in the forty class than found in the previous material but, as has been indicated, the frequency curve of the first cells studied was without definite mode and it may well be that the frequencies in this case are also governed by chance.

All that has been said on the structure of chromosomes on page 163 applies to the chromosomes of the somatic cells as well as those of the germ cells.

\section{The behavior of the 'extra' chromosomes}

The chromosomes of the spermatogonia have been shown to be constant in number, while those of the soma have a rather wide range. Regardless of how this variation has come about it is interesting to know how these 'extra' chromosomes the chromosomes in excess of forty) behave. Are they carried on as a part of the chromatic complex or are they thrown out to degenerate in the cytoplasm? My evidence on this point is not very conclusive, as it is difficult to find anaphase stages oriented in the proper plane and at just the right stage for counting. In one case, however, I was able to make a fairly accurate count of the chromosomes at one pole of an anaphase group. In figure 57 the plate placed toward the upper side of the page 
shows at least forty-three chromosomes. There are very likely more present, but forty-three chromosomes were readily discernible. At the lower pole only thirty-six chromosomes were distinguishable, but the spindle axis was slightly oblique to a perfect polar view and consequently it was impossible, even to approximate the actual number of chromosomes present. It is evident in one case, at least, that the 'extra' chromosomes behave as do the others and divide regularly. It is rarely that I have found a cell in anaphase with the chromosomes trailing on the spindle after the others had reached the poles as might be expected if these 'extra' bodies were eliminated. Figures 86 and 88 are thought to be two such cells. In figure 86 there is an area surrounding a trailing chromosome that is lighter in color than the cytoplasm and which appears as the beginning of a vesicle. This vesicle might cause the disintegration of this chromosome outside of the nucleus. The evidence for this, however, is very poor. Evidence from another form on the constancy of the complex will be mentioned presently in support of the above statements.

\section{The cause of the variation in number}

Since the chromosomes of the male germ cells are constantly forty in number, how has the soma acquired the wide range of number that has been described? One explanation. would suggest that they are giant cells, or perhaps what may be termed partial giants, due to the division, but lack of separation of eertain chromosomes, as found by Dr. Caroline Holt ('17) in the cast off lining of the -intestinal wall in Culex pipiens. This is not likely for several reasons. In the first place the multiple chromosome cells in Culex are degenerating and abnormal, while the cells in the pig which show variation in chromosome number are perfectly normal in appearance and size, and are part of active, healthily growing tissue. When the somatic cells are compared with the giant spermatogonium reproduced as figure 14, it is very obvious that the cells of the soma are much smaller and appear, so far as the diameter of the metaphase plate is con- 
cerned, like normal spermatogonial cells. The other possibility is that the chromosomes in the somatic cells have fragmented. This suggested itself to me particularly, as I had discovered that the variation in the number of somatic chromosomes in the evening primrose, Oenothera scintillans, is due to the fragmentation of certain chromosomes (Hance, '18). In the case of Oenothera scintillans I found the chromosomes showing deep constrictions which led to the solution of the problem in this instance. The conditions in $O$. scintillans will be discussed later. Although I have searched for such constrictions in the chromosomes of the pig, I have never found any of which I could be certain. In several cases chromosomes have been found in which there appeared to be a constriction but this interpretation was always open to considerable doubt. In figure 36 , to the left of the number is one of the best cases of a thin area in a chromosome that $\mathrm{I}$ have found. One of the chromosomes in figure 85 also shows constrictions. When a large number of chromosomes are concerned, it becomes a matter of considerable difficulty to determine whether a chromosome has been found showing a constriction or whether this dent is really due to the overlapping or approximation of two chromosomes. Although it has been impossible actually to demonstrate the possibility of fragmentation through the discovery of constrictions in the chromosomes, there are, however, indirect methods of proving that this process is going on in the pig. If the chromosomes are breaking up we would expect to find, as in the case of Oenothera scintillans, that those cells showing a high degree of fragmentation would give ocular evidence of the fact by possessing visibly shorter chromosomes. Those cells which possess only a few more than the spermatogonial number of chromosomes should appear like the germ cells, while those having forty-five or more should have chromosomes which are obviously shorter. A comparison of a cell having many chromosomes with others in the same tissue, or in other tissues having the spermatogonial number or very close to it, will show that the chromatin bodies in the many-chromosome cells are in general, shorter. Compare figures 23 to 80 with figures 1 to 20 and the photomicrographs 96,97 and 98 with 99 . 
With the ocular evidence in favor of the breaking up of the somatic chromosomes, further evidence indicating that such a process is actually taking place may be offered. That the 'extra' chromosomes divide and behave normally has been described above. They are not as a rule at least, lost from the complex. If the extra chromatin bodies present are not due to additions to the regular nuclear equipment, but rather to the breaking up of the type chromosomes, the total length of all of the chromosomes in any somatic or spermatogonial cell, regardless of the number of separate elements possessed, should be approximately the same. The results of an investigation to determine this point follow.

\section{THE METRIC ANALYSIS OF THE CHROMOSOMES}

In studying the chromosomes, use has been made of the method first developed in the work on the evening primrose, Oenothera (Hance, '18). Measurements of chromosomes have been made before, but the discovery of the exact inter-pair relationship is, in somatic cells as far as I am aware, new, and should prove of considerable value in studying cytological data (particularly in the determination of the chromosomes involved where irregularities occur). Since these methods were worked out I find that Robertson ('15) has employed the relationship of certain chromosomes expressed in ratios in some of his Orthopteran studies. This will be referred to in the discussion. Sutton ('02) was the first to determine the paired condition of the germinal chromosomes. He pointed out that the pairs differed in length and maintained a definite and constant size from one cell generation to another, and also that the pairs, when arranged according to length formed a practically uniformly graded series. Meek ('12a, ' $12 \mathrm{~b}$ and '15) has also made extensive measurements. These methods permit the accurate checking of results and eliminate, to a large degree, the personal element which so frequently enters cytological work. Relationships not optically discernible are brought out, and the application of the method to the work of others enables an investigator to check his work as regards accuracy and interpretations. 


\section{Spermatogonia}

Total length of the chromosomes. The total lengths of the chromosomes in the spermatogonia at 20,400 magnification were found to range from 118.6 centimeters to 177.6 centimeters with an average of 136.9 centimeters. A glance at figures 1 to 20 will show the reason for this wide variation. Cells differ considerably in the size of the chromosomes, although it is apparent from the figures and from the measurements, that each chromosome of a cell suffers equally in any reduction or gains proportionally in an increase of size. I have reported the same conditions, rather more marked, in the somatic cells of the mosquito (Hance '17 a). This may be due to differences in nourishment, or, as in the case of the production of extra contractile vacuoles in paramaecium (' $17 \mathrm{c}$ ), to a rapidity of division which does not permit the chromosomes time to grow to the limits of their possibilities. A graphic illustration is given in text figure 2 of the minimum, maximum and average length of the spermatogonial chromosomes.

That figure 14 is a giant cell is readily demonstrated when the chromosomes are measured. Although the total lengths of the spermatogonial chromosomes has been found to vary between 118.6 and 177.6 centimeters, the chromosomes of figure 14 measure 235 centimeters, or 58 centimeters longer than the longest set of chromosomes.

Pairs and relation of pairs. When the chromosomes of the spermatogonia are arranged according to length, it is found that they form a series which falls very gradually from the long end of the series to the short end. This may be seen in plate 9, row 1 , and it is more clearly shown by the heavy black band in text figure 3. The pairing is not as strikingly obvious as in the case of Oenothera scintillans, but, considering the chances of error in drawing a large number of small chromosomes, I believe that the pairs stand out fairly well. In the table below the average lengths of the spermatogonial chromosomes are listed. Frequently the mates are found near each other in the complex but not always. 


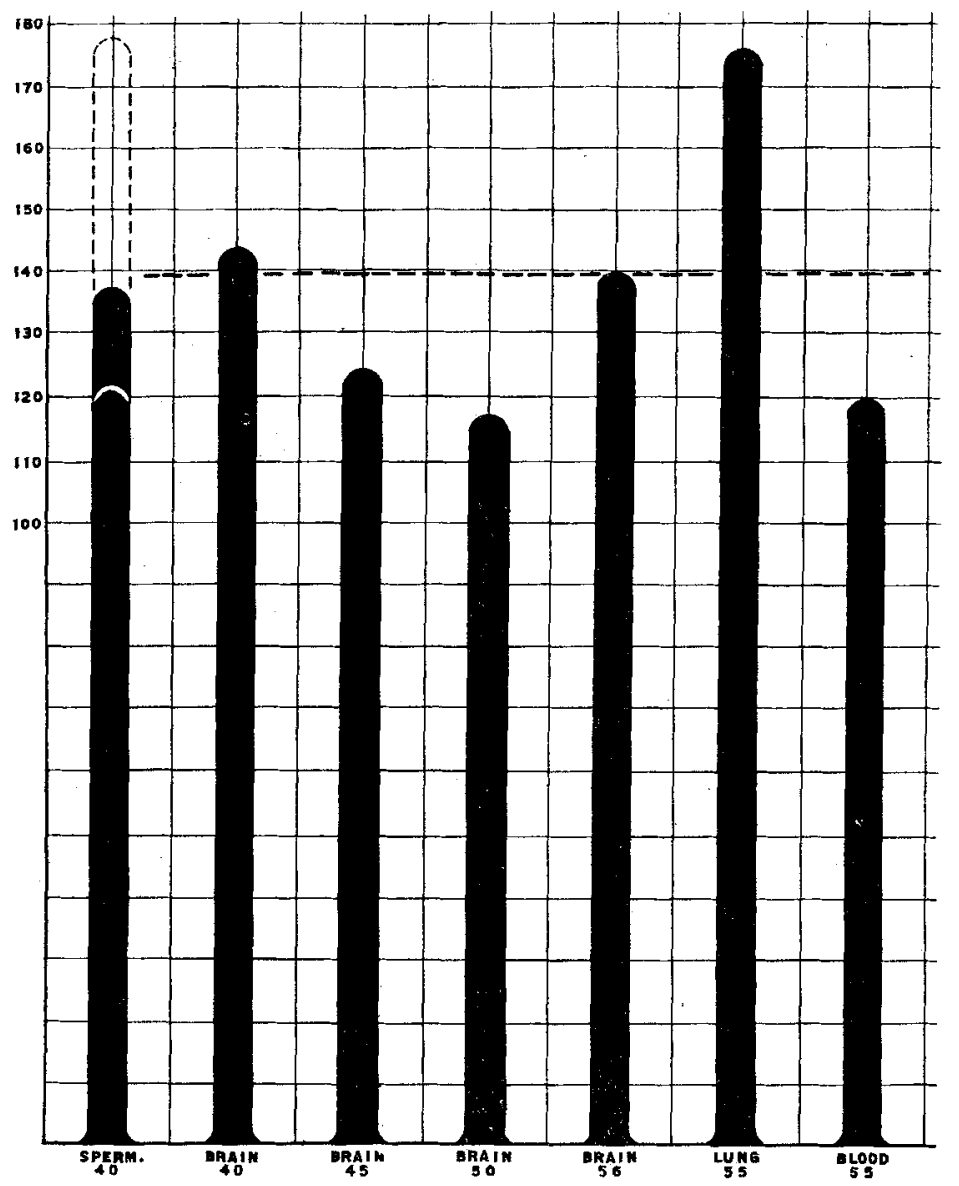

Text fig. 2 A graphic illustration of the total lengths of the chromosomes of the spermatogonia and in different body cells which have undergone various degrees of fragmentation. The figures to the left refer to the length in centimeters. The dotted addition to the pillar representing the spcrmatogonia indicates the greatest length found and the white line shows the minimum for these cells. The heavy dotted line across the diagram represents the average length of the chromosomes of somatic cells. Note that the total leng,ths of the somatic chromosomes fall within the limits found for the spermatogonia and that the average Iength for these colls is almost identical to the spermatogonial average. 


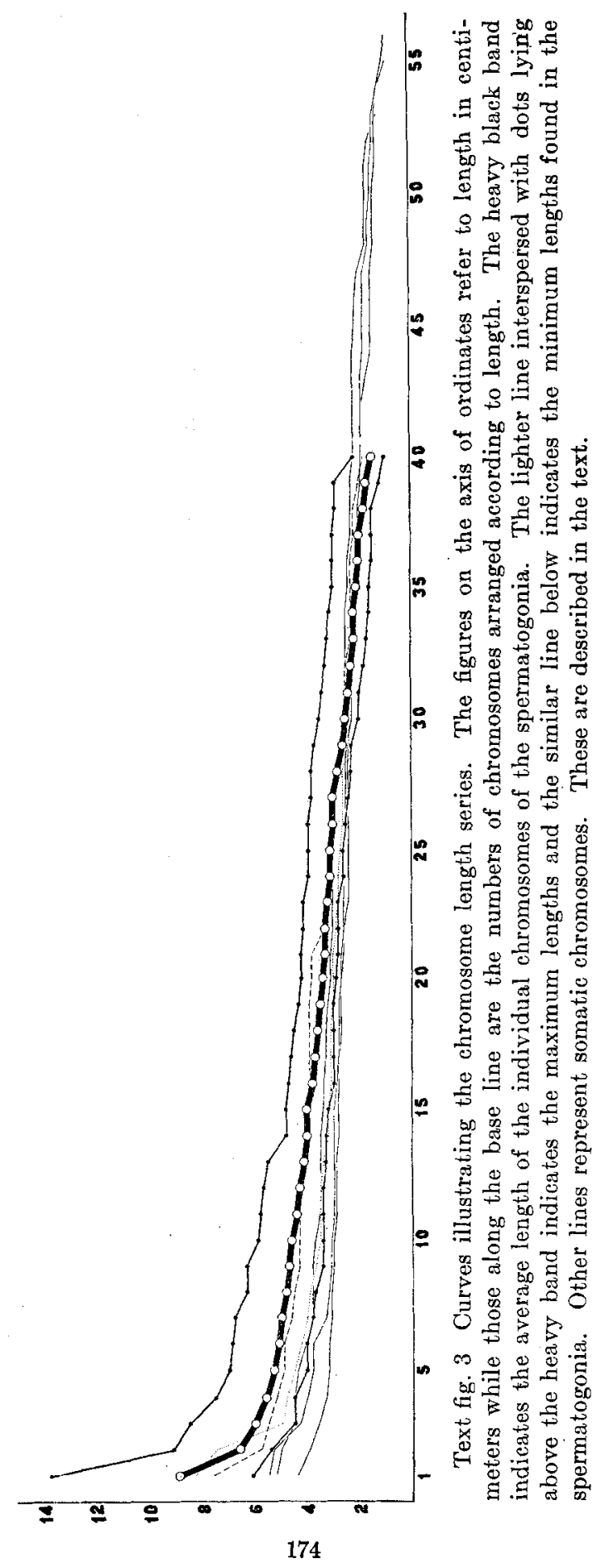


Table of spermatogonial chromosome lengths, pairs and relations

\begin{tabular}{|c|c|c|c|}
\hline PAIR & CHROMO\&OME & LENGTH IN CENTIMETERS & $\begin{array}{c}\text { RELATION OF PAIRS IN } \\
\text { PER CENT }\end{array}$ \\
\hline 1 & $\begin{array}{l}1 \\
2\end{array}$ & $\begin{array}{l}8.9 \\
6.6\end{array}$ & 74 \\
\hline 2 & $\begin{array}{l}3 \\
4\end{array}$ & $\begin{array}{l}6.0 \\
5.6\end{array}$ & 89 \\
\hline 3 & $\begin{array}{l}5 \\
6\end{array}$ & $\begin{array}{l}5.3 \\
5.1\end{array}$ & 94 \\
\hline 4 & $\begin{array}{l}7 \\
8\end{array}$ & $\begin{array}{l}5.0 \\
4.8\end{array}$ & 96 \\
\hline 5 & $\begin{array}{r}\theta \\
10\end{array}$ & $\begin{array}{l}4.7 \\
4.6\end{array}$ & 96 \\
\hline 6 & $\begin{array}{l}11 \\
12\end{array}$ & $\begin{array}{l}4.4 \\
4.3\end{array}$ & 98 \\
\hline 7 & $\begin{array}{l}13 \\
14\end{array}$ & $\begin{array}{l}4.1 \\
4.0\end{array}$ & 95 \\
\hline 8 & $\begin{array}{l}15 \\
16\end{array}$ & $\begin{array}{l}4.0 \\
3.8\end{array}$ & 95 \\
\hline 9 & $\begin{array}{l}17 \\
18\end{array}$ & $\begin{array}{l}3.7 \\
3.6\end{array}$ & 95 \\
\hline 10 & $\begin{array}{l}19 \\
20\end{array}$ & $\begin{array}{l}3.5 \\
3.4\end{array}$ & 94 \\
\hline 11 & $\begin{array}{l}21 \\
22\end{array}$ & $\begin{array}{l}3.3 \\
3.3\end{array}$ & 97 \\
\hline 12 & $\begin{array}{l}23 \\
24\end{array}$ & $\begin{array}{l}3.2 \\
3.1\end{array}$ & 97 \\
\hline 13 & $\begin{array}{l}25 \\
26\end{array}$ & $\begin{array}{l}3.1 \\
3.0\end{array}$ & 94 \\
\hline 14 & $\begin{array}{l}27 \\
28\end{array}$ & $\begin{array}{l}3.0 \\
2.8\end{array}$ & 90 \\
\hline 15 & $\begin{array}{l}29 \\
30\end{array}$ & $\begin{array}{l}2.6 \\
2.5\end{array}$ & 92 \\
\hline 16 & $\begin{array}{l}31 \\
32 \\
:\end{array}$ & $\begin{array}{l}2.4 \\
2.3\end{array}$ & 92 \\
\hline 17 & $\begin{array}{l}33 \\
34\end{array}$ & $\begin{array}{l}2.2 \\
2.2\end{array}$ & 96 \\
\hline 18 & $\begin{array}{l}35 \\
36\end{array}$ & $\begin{array}{l}2.1 \\
2.0\end{array}$ & 91 \\
\hline 19 & $\begin{array}{l}37 \\
38\end{array}$ & $\begin{array}{l}2.0 \\
1.8\end{array}$ & 84 \\
\hline 20 & $\begin{array}{l}39 \\
40\end{array}$ & $\begin{array}{l}1.7 \\
1.5\end{array}$ & \\
\hline
\end{tabular}


As a constant relationship between chromosome pairs had been found in Oenothera scintillans, it was of interest to determine whether such exists in the pig. That it does is shown in the above table in the column to the right. There the relationship of the pairs is expressed in terms of per cent, i.e., a shorter pair is a certain per cent of the length of the next longer pair, etc. There is a rather large increase in this percentage relationship at either end of the series. These relationships will be more readily understood from text figure 4 when the heavy black band expresses the percentage of difference between pairs of chromosomes in the spermatogonia, drawn from the figures given above. This curve shows a remarkably uniform difference in length between the pairs, except at the two extremities. In cells in which the total length of the chromosomes is short, all of these have been affected equally in the size reduction, as the percentage relationship between the pairs is the same as between the same pairs of the 'longer' cells.

\section{Somatic cells}

Total lengths of the chromosomes. The total lengths of the somatic chromosomes in the various tissues is given in the following table. As can be seen, the total lengths of the chromosomes in the somatic cells falls within the limits determined for the spermatogonia. The one exception to this statement- the fifty-chromosome brain cell measuring 117 centimeters-falls below the minimum length found for the spermatogonia by such a small amount that I am not inclined to attach any importance to it. The average length of the various cells given above is 139.3 centimeters, which is exceedingly close to the average found for the germ cells, 136.9 centimeters. The lengths from various cells are compared with those of the spermatogonia in text figure 2. It is evident that, since the total length of the chromosomes in the various classes of cells is approximately the same, the increased number of chromosomes must be due to fragmentation.

Figures 23 to 80 show that any tissue may have metaphase plates that vary as much in total diameter as do those of the 


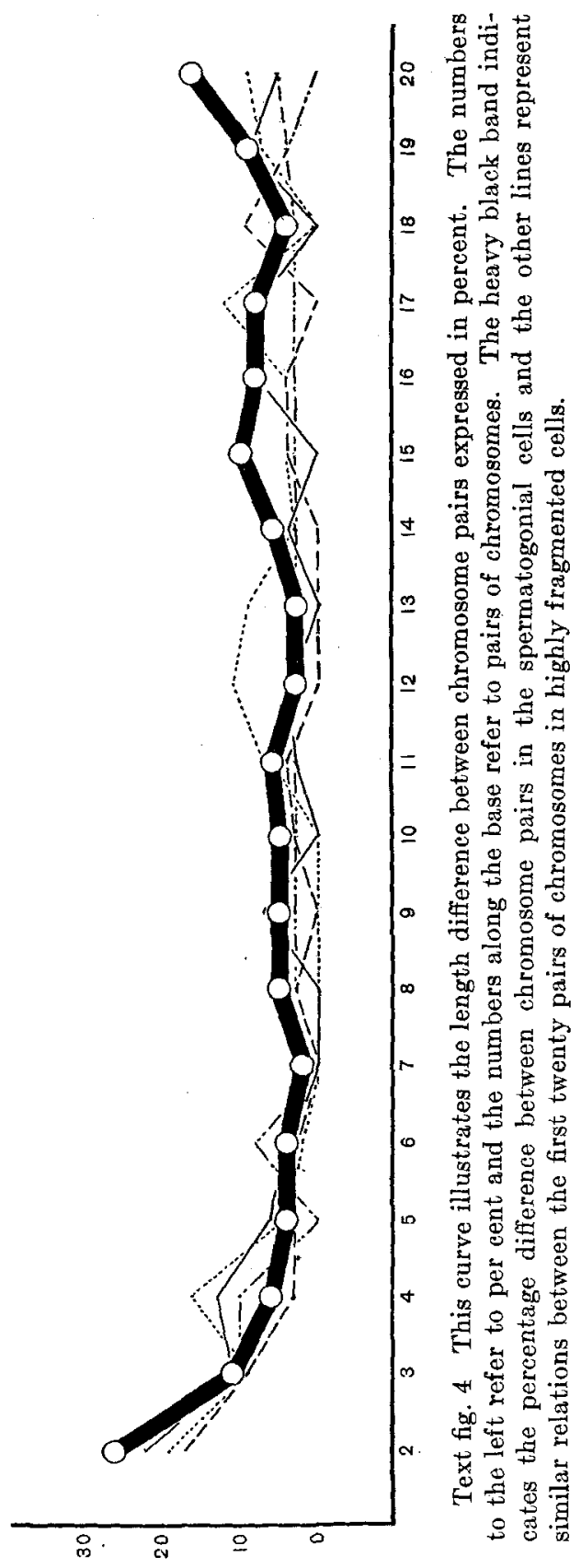

JOURNAL OF MORPHOLOGT, VOL. 30 , NO. 1 
spermatogonia. The measurements given above bear this out. It may be pointed out that, although considerable variation exists between the total lengths of all of the chromosomes in the various cells, this variation is not greater in one tissue than in another and falls within the limits determined for the spermatogonia.

On plate 10 the chromosomes of a number of cells in various degrees of fragmentation are arranged according to size. It is obvious that the somatic chromosomes, particularly at the long end of the series, are shorter than those in the same column in the row devoted to the spermatogonial chromosomes or to the somatic cells possessing forty chromosomes. The conditions illustrated on this plate will be referred to later.

Table of total chromosome lengths in the cells of various tissues and in cells possessing different numbers of chromosomes

\begin{tabular}{|c|c|c|c|}
\hline & TISSUE & $\begin{array}{l}\text { NUMBER OF } \\
\text { CHROMOSOMES }\end{array}$ & $\begin{array}{l}\text { TOTAL LENGTH OF } \\
\text { CHROMOSOMES IN } \\
\text { CENTIMETERS }\end{array}$ \\
\hline \multicolumn{2}{|l|}{ Amnion. } & 41 & 129.2 \\
\hline \multicolumn{2}{|l|}{ Blood... } & 55 & 129.8 \\
\hline \multicolumn{2}{|c|}{ 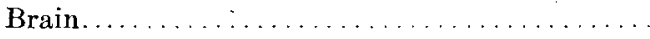 } & 40 & 143.9 \\
\hline \multicolumn{2}{|c|}{ Brain ..................... } & 45 & 124.1 \\
\hline \multicolumn{2}{|c|}{ Brain . . . . } & 50 & 117.0 \\
\hline \multicolumn{2}{|l|}{ Brain.... . } & 56 & 139.9 \\
\hline \multicolumn{2}{|l|}{ Limb bud. } & 52 & 152.6 \\
\hline \multicolumn{2}{|c|}{ Liver............... } & 53 & 158.4 \\
\hline \multicolumn{2}{|c|}{ 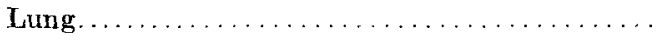 } & 55 & 176.1 \\
\hline \multicolumn{2}{|c|}{ 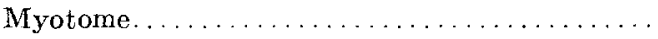 } & 43 & \\
\hline \multicolumn{3}{|c|}{ 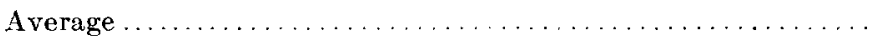 } & 139.3 \\
\hline
\end{tabular}

The length of the chromosome fragments. In my studies on Oenothera scintillans I considered all the chromosomes which, when arranged according to length, fell below the shortest chromosome in the normal diploid series, to be portions or fragments of longer chromosomes and I found then to be remarkably alike in length. When the chromosomes on plate 9, to the right of chromosome 40 , are studied, it is evident that they, too, vary but little. By actual measurements they aver- 
age 17 millimeters, with one extreme measuring 9 millimeters and the other 25 millimeters. The majority approach very near the average length. Recalling that the longest chromosomes of the series average 8.9 centimeters, it seems justifiable to consider the chromosomes below chromosome 40 in the length series to be very nearly of even size in the majority of cases.

Discussion of the results obtained by measuring the chromosomes

The conditions in Oenothera scintillans. In order that the metrical studies of the chromosomes of the pig may be better understood a synopsis of similar work on Oenothera scintillans (Hance '18) is given below. As the chromosomes in this Oenothera were much less numerous than in the pig, more clear cut and definite results were obtained, and they aided greatly in the interpretation of the observations on the latter.

1. In material collected from three generations of Oenothera scintillans the somatic chromosome number varies from 15 to 21 . This variation is not correlated with any particular tissue, but exists throughout the plant.

2. The type or fundamental number of chromosomes is 15 .

3. The 'extra' chromosomes divide regularly.

4. Each pair of the type (15-chromosome) group differs from the next pair in the series by 9 per cent, or a shorter pair is 91 per cent the length of the next longer pair. This is apparently a constant relation.

5. The 'extra' chromosomes have been shown to be fragments of the type chromosomes, and the total length of the chromosomes in the various classes of cells has been found to be practically identical. The fragments are very nearly of even length.

6. With the aid of the paired conditions of the chromosomes and of the relation between the pairs, it has been found possible theoretically to reunite the fragments with the chromosomes from which they have separated.

7. Fragmentation in the cells studied, has been confined largely, but not exclusively, to the longer chromosomes.

8. Fragmentation does not occur in the germ line. 
The conditions in the pig. With the increase in the number of the chromosomes the difficulties of analysis are increased. It is consequently necessary to know how far we may trust the accuracy of the present work before it is possible to draw conclusions from the results. If the majority of the results obtained in the present study can be shown to be safely comparable to those obtained on $\mathrm{O}$. scintillans, it will be justifiable to assume that the conclusions reached for the earlier and more favorable form will be applicable to the pig.

A very interesting relation exists as regards the degree of fragmentation in the two forms. Considering only the cells in which the highest number of chromosomes is found in both the Oenothera (21 chromosomes) and the pig ( 57 chromosomes) in comparison to the type or fundamental numbers (15 and 40 respectively), it becomes evident that the evening primrose has suffered a fragmentation of 40 per cent of its chromosomes and the pig of 42.5 per cent. While future work may show that this percentage of fragmentation may mean nothing and is merely a coincidence, for the present it is suggestive.

To review briefly the results obtained in the study of the chromosomes of the pig:

1. The spermatogonial number is 40 .

2. The somatic number as determined in the present study ranges from 40 to 58 .

3. The 'extra' chromosomes divide as do the type chromosomes.

4. A difference averaging 12 per cent has been found to exist between spermatogonial pairs. If the relationships of the length of the pairs on either end of the series be omitted the average per cent is but five.

5 . The total length of the chromosomes of any somatic cell, regardless of the number of chromosomes or of the tissues of which it is a part, falls within the length limits found for the spermatogonial chromosomes.

6. The 'extra' chromosomes, for reasons set forth above, must be fragments of the normal chromosomes.

7. The fragments are very nearly of even length. 
8. Fragmentation does not affect the germinal chromosomes.

A comparison of the conditions in the two forms. When the summary of the observations on the pig is compared with the preceding one on Oenothera scintillans it is plain that, with one or two exceptions, the words pig and Oenothera could be interchanged without affecting the truth of the statements in the slightest. The relationship between the pairs differs slightly, but is, however, fairly constant in both species. The chief discovery in the case of the Oenothera is that it is possible to reunite the fragmented chromosomes and thus determine, with a fair degree of accuracy, which chromosomes have broken up. Is this method of procedure applicable to the chromosomes of the pig? Can the chromosomes which have fragmented be located? The chance of even approximate accuracy in attempting to reunite the fragmented chromosomes of the pig is so slight that it would be unwise to base any conclusions on the results. This is true for the following reasons: 1) The large number of chromosomes and the consequent and very probable slight inaccuracies in drawing are prohibitive of the success of such a study. 2) The very slight differences, in the majority of instances, between the chromosome pairs present no definite criterion on which to base judgment as to which chromosomes are out of place in the series and consequently with which fragments they should be united.

It is possible, in a more direct way, however, to determine which chromosomes of the series are breaking up. The method is not so completely satisfactory as the one used with the evening primrose, but serves to show, in a general way and with a considerable degree of accuracy, which end of the chromosome series is breaking up. In plate 9 it will be recognized at once that, in general, in those somatic cells (row 3 to 12) possessing a large number of chromosomes, the chromosomes at the beginning of the series are shorter than the chromosomes of the spermatogonium (row 1) and of the unfragmented brain cell (row 2) in the same columns. There are exceptions to this which tend to show that, in breaking up, the chromosomes may not follow a definite plan beginning with the long chromo- 
somes and proceeding down the series. In row 6 a 41 -chromosome cell is represented. Here the first two chromosomes are very clearly entire, judging their lengths by those of the first two chromosomes of row 1 . It appears very probable that either chromosome 3 or 4 has been the one to lose the portion represented by chromosome 41 . In row 11 the first two chromosomes are long, but so, also, are the other chromosomes in this cell, and when considered from this point of view these chromosomes are relatively very nearly as short as the first pair in row 10 . The chromosomes in row 11 measure $176.1 \mathrm{~cm}$., while the total length of those in row 16 is $153.6 \mathrm{~cm}$. Row 11 is therefore 8.8 per cent longer than row 10 . If the total lengths of the chromosomes vary by 8.8 per cent then, according to the statements made above that in reduction (for whatever reason) each chromosome suffers proportionately, any corresponding pairs from either of the cells should differ by very nearly the same amount. It is, of course, not expected that exact results may be obtained in all cases for reasons pointed out earlier. Consider for example the pairs composed of chromosomes 1 and 2 in rows 10 and 11 . These chromosomes average $5.1 \mathrm{~cm}$. in length in row 10 and $6.7 \mathrm{~cm}$. in row 11. and consequently differ by 7.6 per cent. In this instance there is a discrepancy of 1.2 per cent. When the next pair in each cell is compared it is found that the difference is 8.8 per cent exactly the same as the variation between the total lengths. This is sufficient, I think, to indicate that the difference in total length is due to a proportional reduction of the chromosomes of row 10 and that the corresponding pairs in each of the rows are comparable. Furthermore it is evident that the longer chromosomes in both rows have in all probability lost a portion of their length since they are shorter than the corresponding 'typical' pairs.

The fact that it is the members of the long end of the chromosome series which are breaking down becomes more evident in text figure 3. For the sake of clearness the graphs for only three greatly fragmented cells have been drawn. These are represented in light unbroken lines. Note that in all three cases the curves start out below the curves representing the 
minimum lengths found for the spermatogonial chromosomes. One cell enters within the spermatogonial minimum curve at chromosome 3 and continues, either on it or very close to it, for a considerable distance. This, however, is a 'longer' cell than the other two and would be expected to rise above the type minimum more quickly than the others. It does not, however, rise noticeably above the minimum curve at the long end of the series, notwithstanding its extra total length. The other two curves do not rise above the minimum curve until chromosome 27 is reached. These three cases, which are typical for others, most certainly show that the chromosomes at the long end of the series have been reduced considerably in length. This becomes especially clear when the broken lines in text figure 3 are followed! and contrasted with the results mentioned above. These curves represent one cell with unfragmented chromosomes and another in which there is a single fragment. The curves lie within the extremes of the spermatogonial lengths for the full distance, and the curve representing the chromosomes of the unfragmented cell coincides with the spermatogonial average curve for a great part of its length.

Hence it seems entirely justifiable to claim that, although the exact chromosomes which have broken up cannot be ascertained, as was done in the case of Oenothera scintillans, the same general conditions hold true, namely, that the chromosomes of the long end of the series have fragmented. This, of course, does not exclude the possibility that some of the shorter chromosomes have broken up. Since this was discovered in Oenothera scintillans, and since the other conditions in both forms are so comparable, it seems probable that the fragmenting of some of the shorter chromosomes may occur in the pig. Neither has it been possible to show that a chromosome has not lost more than one piece. For various reasons, however, I am, at present, inclined to think that a chromosome does not lose more than one piece or, if it does, that the condition is rare.

The point of fragmentation. That the fragments should be so nearly of even length in the two forms studied is very suggestive. and would seem to indicate that one or two chromomeres have 
broken off and that the loss is limited to that amount of chromatin. Since the fragments are fairly uniform in length, the chromosomes must be reduced by more or less equivalent amounts, and consequently we should not expect to find the percentage relation between the pairs showing any marked variation from that found between the spermatogonial pairs. This is shown graphically in text figure 4 where the percentage relations of the first twenty pairs of four highly fragmented cells are plotted. As can be seen, the curves vary but slightly from the spermatogonial curve.

It has been pointed out that the long chromosomes are the chief ones involved in fragmentation. A study of the longer chromosomes Plate 10 , rows 1 and 2 (unfragmented cells) reveals that several are J-shaped or formed as an unequal armed $\mathrm{V}$. Assuming that the point of spindle fiber attachment is located at the apex of the $J$ (page 163) the possibility that fragmentation has occurred at this point immediately suggests itself since the short arm of the chromosome is in many cases approximately the length of the chromosomes (the fragments) lying above 40 in the fragmented series. It will be noted on Plate 10 that there are several J-shaped chromosomes in those rows representing cells in which little or no fragmentation has occurred. With an increasing degree of fragmentation the number of curved chromosomes becomes less and less. In cells with high numbers of chromosomes those lying in the same columns as the curved chromosomes of rows 1 and 2 are generally rod-shaped. While this is but circumstantial evidence it offers a logical and interesting explanation of the process as occurring in these cells. It is, of course, but a tentative theory which may be proved or overthrown by further work.

\section{DISCUSSION}

The work of other mammalian cytologists

The amount of published cytological work on the mammals is neither large nor reliable, when compared to that which has been done on other forms as, for instance, the grasshoppers and 
the bugs. Since the present paper deals with the diploid number alone, I will consider only that part of the reported mammalian investigation. It is rather interesting to note the elaborate descriptions of the resting and prophase conditions and the brief consideration and few figures of the chromosomes themselves. The inference is rather obvious, and it is partly to counteract the impression that sufficiently clear, and easily studied chromosome complexes are scarce in mammalian material, that I have presented the large number of figures at the close of this paper.

The investigation of the most importance to the present study is Wodsedalek's work on the pig ('13). He has reported 18 chromosomes in the spermatogonia and 20 in the ovary. He also found two classes of embryos, one with 18 and the other with 20 chromosomes. He figured two X-chromosomes. The discrepancy between Wodsedalek's count of 18 chromosomes and my own of 40 chromosomes in the same type of tissue is rather large, and I feel sure, has been due largely to the difference in the methods of preparing the material. In a paper on "The fixation of mammalian chromosomes" ('17 b) I have described the result of fixing mammalian tissue with various fluids, and also the effect of fixing stale tissue (which, indeed, may not have been removed from the body for more than 15 to 20 minutes). Wodsedalek's figures are practically identical with those I have found in either poorly fixed tissue or in tissue that was dead when preserved. The cbromosomes are clumped and undecipherable, as is evident in the one spermatogonial and three embryonic diploid cells figured in Wodsedalek's paper. A very interesting condition seems generally to occur when chromosomes clump together as the result of poor fixation. The number is reduced to approximately one half through the fusion of chromosomes lying along side of each other-probably mates. In the case under discussion, Wodsedalek's count is two less than one half of the count I have made. In this condition, such chromosomes as can be distinguished at all, are at least double the width of those found in properly fixed material. It is very evident that such poorly preserved tissue should never be accepted as avail- 
able for study, since any conclusions based on such material are not only open to criticism, but are very probably wrong. A form possessing so large a number of chromosomes as the pig enclosed in so small a compass must, indeed, be prepared with the greatest care if results of any value are to be obtained.

It is possible to show more conclusively that the diploid chromosomes of Wodsedalek's pig possess the same amount of chromatin as I have described for the number of individuals studied. If a fusion between adjacent chromosomes, or perhaps between pairs, has occurred, the total length of the chromosomes in Wodsedalek's figures should be about one half the length I have found. Furthermore, the chromosomes (provided the magnification was the same) should average about twice the width of those figured in this paper. It seems probable that, however much the widths may have been effected through poor fixation, the lengths may not have been greatly disturbed, or, if they were shrunken, the shrinkage would affect all alike. Consequently I believe that the measuring of these chromosomes may be relied upon to give fairly accurate results. The chromosomes of the four figures in his paper were copied and enlarged six times over the published size as carefully as possible with the following results.

The length of the chromosomes in the figures of the diploid complexes published in Wodsedalek's article on the spermatogenesis of the pig ('13)

\begin{tabular}{|c|c|c|c|}
\hline TISSOE & $\begin{array}{l}\text { FIG URE } \\
\text { NUMBER }\end{array}$ & $\begin{array}{c}\text { NUMBER OF } \\
\text { CH ROMOSOMES }\end{array}$ & $\mid \begin{array}{r}\text { TOTAL } \\
\text { LENGTH } \times 6 \text { IN } \\
\text { CENTIMETERS }\end{array}$ \\
\hline Spermatogonium............ & 18 & 18 & 56.5 \\
\hline 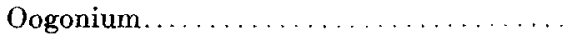 & 60 & 20 & 49.2 \\
\hline Mesonephros.................. & 59 & 18 & 44.3 \\
\hline 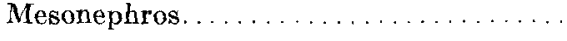 & 62 & 20 & 47.6 \\
\hline \multicolumn{3}{|l|}{ Average. } & $\begin{array}{c}49.6 \\
\text { or approxi- } \\
\text { mately } \\
50 \mathrm{~cm} .\end{array}$ \\
\hline
\end{tabular}

The magnification used by Wodsedalek was about one third less than that I have employed. Consequently one third must 
be added to $50 \mathrm{~cm}$. to bring it up to a magnification corresponding to that used in the present work- $50+16=66 \mathrm{~cm}$.

The total average length of the spermatogonial chromosomes in my material $-136.9 \mathrm{~cm}$.

The total average length of the dipoid chromosomes in Wodsedalek's material $-66.0 \mathrm{~cm}$.

The length of the latter chromosomes is 48 per cent that of the upper lot, or very nearly one half $-66 \mathrm{~cm} . \times 2=132 \mathrm{~cm}$. This is so near the average length of the spermatogonial chromosomes found in my work as to be practically identical. In the same way the widths may be determined. I was hampered again by being unable from the figures to determine certainly the limits of the chromosomes, but I think that any error that may have been introduced has been largely checked by averaging the results.

Average chromosome width-12 mm.; $+\frac{1}{3}$ magnification-16 $\mathrm{mm}$. Average chromosome width in my material $-7 \mathrm{~mm}$.

The first set is a trifle more than double the width of the latter, not a sufficiently great difference, however, to be significant, considering the chances of error. Text figure 5 illustrates the above results graphically. At the right is the figure of the spermatogonial chromosomes in Wodsedalek's paper, and a column drawn to scale from the above calculations illustrating the average total length and average width of the chromosomes. To the left are corresponding figures representing the present work. This column is obviously a little over twice as high and one half as wide as the column to the right. The area of the left hand column (as reproduced) is 468.5 square $\mathrm{mm}$; of the right hand column, 441 square $\mathrm{mm}$. It is safe to conclude therefore that both Wodsedalek and myself have been dealing with the same amount of chromatin, and the difference lies wholly in the difference of the preservation of the chromosomes; those in the former study being clumped and undecipherable, while those reported here are well separated.

Though I have little, direct proof to offer at present, J am inclined to believe that other features of the chromosome history reported in the earlier paper, particularly as regards the num- 
ber of chromosomes in the first and second spermatocytes, and the secondary reduction phenomena in the second spermatocytes, were influenced by the same conditions which affected the number of spermatogonial chromosomes. The first spermatocyte cells that I have counted have had twenty chromosomes, and the secondary spermatocytes-although I have not found
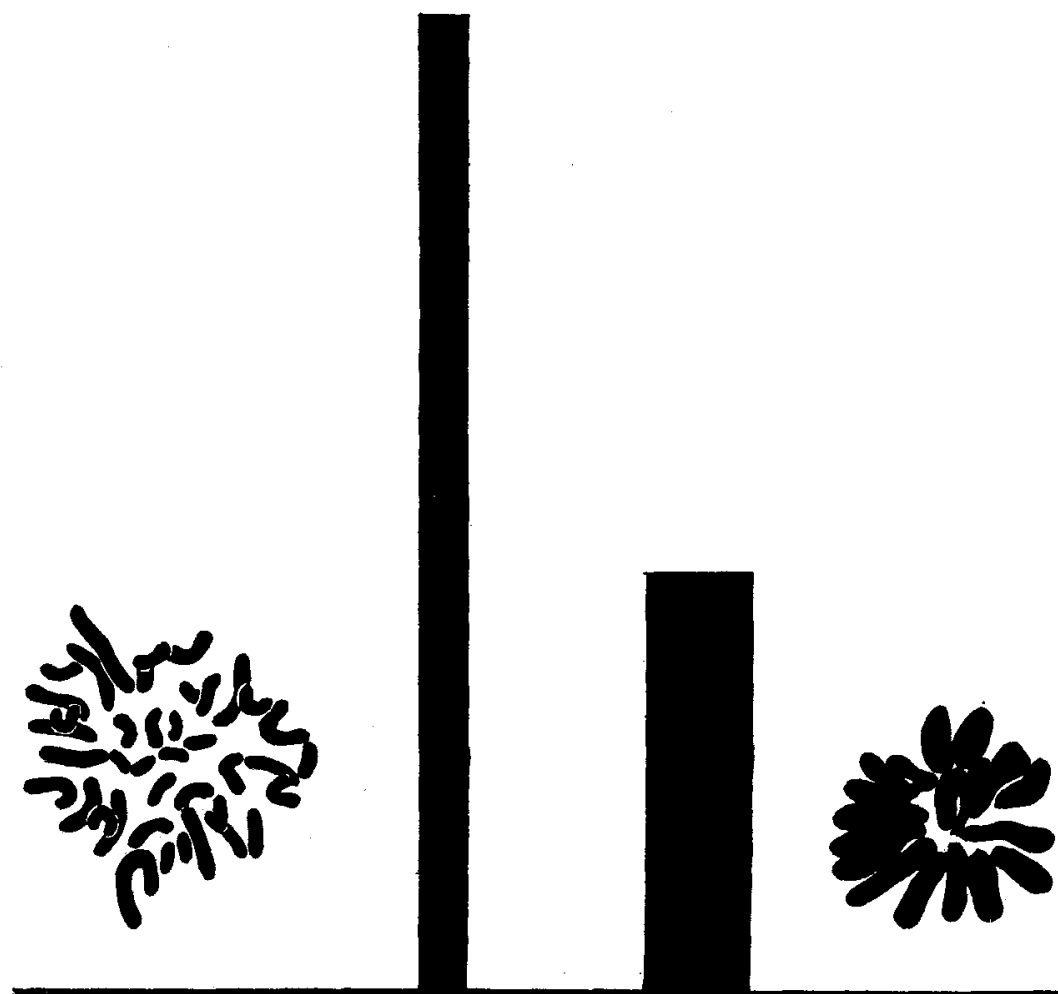

Text fig. 5 A diagrammatic comparison of the amounts of chromatin in pig spermatogonia studied by Wodsedalek and myself. The metaphase plate to the left shows forty chromosomes $(\times 3400)$, the column next to it represents the total length of the chromosomes and average width or diameter of the spermatogonial cells. The column and chromosome group (showing presumably eighteen chromosomes ( $\times 3495)$ ) to the right illustrates the same features for the spermatogonial figure published by Wodsedalek. It is evident that the pillar to the left is about twice as high and one half as wide as the one to the left, both consequently possessing the same area. See text. 
any in which an accurate count could be made-have shown no tendency to a secondary or pseudo-reduction. Neither have I, in the present study, seen any bodies comparable to the $\mathrm{X}$-chromosomes shown in Wodsedalek's figures. In poorly fixed material obtained some years ago I have seen similar bodies. This problem I hope to take up shortly.

Other cytological work carried out on mammals includes studies on man by Flemming ('98), Farmer and Moore ('05), Moore and Arnold ('06), Duesberg ('06), Guyer ('10), Montgomery ('12), Winiwarter ('12), Jordan ('14) and Wieman ('13 and '17). The diploid number as given by these workers varies from 22 to 47 or 48 . The rabbit is claimed to have chromosomes ranging in number from 22 to 80 . This form has been studied by Flemming ('98), Winiwarter ('00), (who believes that the somatic number ranges from 42 to 80 ), Barratt ('07) and Bachhuber ('16), Miss Stevens, in 1911, reported 56 chromosomes for the guinea pig. Vom Rath, in 1894, found the somatic chromosomes in the dog to range from 8 to 64 , and pointed out that the various numbers were always multiples of eight. Winiwarter and Sainmont ('09) described 36 chromosomes for the sex and somatic cells of the cat. In the opossum Jordan ('11), found 17 chromosomes in both germ and somatic tissue. Schoenfeld's work on the bull ('07) is largely a study of the prophase behavior, and the number of chromosomes is not given. Wodsedalek found 37 chromosomes in the horse ('14) and 51 chromosomes in the mule ('16). Yocum ('17) has reported 20 chromosomes as the reduced number in the mouse. He has not counted any spermatogonial complexes. His drawings show the chromosomes to be much better separated than is the case in the majority of published mammalian studies.

If we may judge the accuracy of the count from the character of the published figures accompanying the above papers, I believe that we are justified in accepting but few of the writers' conclusions. The chromosomes are massed together, as shown in the case of Wodsedalek's work on the pig, and it seems very likely that fusion of the chromosomes has occurred in the various forms mentioned above, as has been shown to have occurred 
in the previous work on the pig. In a study of the tissues from seven mammals in connection with work on "The fixation of mammalian chromosomes" (Hance, '17 b) the chromosomes of none of the forms studied, when killed and treated in the proper way, were clumped together or variable in width. They did not look like amorphous lumps of stainable material which is the appearance of many of the mammalian chromosomes in published figures. Furthermore, the number was always high, in all cases about 40 or more. With a large amount of material from so many mammals, I think that I have a fair basis for the criticisms I have made of the mammalian cytological studies up to date. Winiwarter's work stands out above that of other workers, if we may judge the excellence of his fixation from the clearness of his published figures. The diploid chromosomes he figures for the cat are very comparable, in form and number, to those I have found in this animal. I have already suggested ('17 b) that when a study of human cytology is repeated on properly preserved and freshly killed tissue, the number of chromosomes will be nearer that reported by Winiwarter than by other investigators. The variations in the somatic chromosome number which he has found in the rabbit are very suggestive from the point of view of the present work and will be considered later. Miss Steven's figures of the spermatogonia of the guinea pig (11), although she found but few clear cells, appear to justify her count of 56. Wieman's prophase figures, in his paper on the chromosomes found in a human embryo appear considerably better than do his later figures on the spermatocytes ('13 and '17). Wodsedalek's figures of the chromosomes of the mule ('16) are somewhat better, as regards separation, than those in his papers on the horse and the pig, but all leave much to be desired in the way of regularity of chromosome outline and differentiation of chromosomes.

\section{Reported cases of fragmentation}

The most familiar case of variation in somatic chromosome number is that of Ascaris megalocephala reported by Boveri. Here the fertilized egg starts with two chromosomes, and the 
cell, which may be considered as the anlage of the future germ cells, retains the two chromosomes intact, while the chromosomes of the cells forming the body tissues break up into as many as sixty fragments. This fragmentation is said to be accompanied by a chromatin diminution. If this be true, the quantity of the chromatin in the cells of the soma is probably not the same as it is in the germ line, contrary to what I have found in the pig and in Oenothers scintillans. A metrical study of the chromosome behavior in Ascaris would be of considerable value. Nachtsheim ('13) found 32 diploid chromosomes in the bee, while Petrunkewitsch ('13) found 64 in the blastoderm of fertilized eggs. Hoy ('16) points out that "though the reports of several investigators tend to show that the number of chromosomes varies in the bee, the number is always 8 or a multiple of this." (Nachtsheim found that the number in the oogonia was 16 and in the oocytes 8 . He considers that oogonial chromosomes are double, thus accounting for the 32 chromosomes found in the soma.) This condition is from one point of view, comparable to that found by Dr. Caroline Holt ('17) in the cells of the cast off intestinal epithelium of the mosquito, where the number varied from 6 to 72 , always in multiples of three. These are degenerating and consequently pathological cells, and differ in this respect from the normal cells of the bee.

In the Hymenopter, Nematus ribesii, Doncaster ('07) found the diploid and the haploid chromosome number to be 8 and 4 respectively, while he counted 16 chromosomes in the ovarian sheath. He considers that the chromosomes of the germ cells may be compound and consist of a number of smaller units which become separated in the somatic cells.

I am glad to have this opportunity of correcting two regretable errors that were accidentally inserted in my paper on Culex pipiens ('17) in regard to Seiler's work on Phragmatobia ('14). In one place I coupled his name with Taylor's as having worked on the mosquito, when the other name should have been I.ohman, and, in referring to his work on the moth, said that he found the somatic chromosome number to be the same as the diploid number of the germ cells. The diploid number is 56 
although 58,61 and 62 chromosomes have been found in the soma. This has been brought about by the fragmentation of the $\mathrm{X}$ and $\mathrm{Y}$ chromosomes. It is confined to these bodies, and Seiler points out that the breaking up of the sex chromosomes in somatic nuclei has been observed quite often.

The extra number of chromosomes found in giant cells is not due to the same causes as the above, and they are found in the germ tissue as well as in the soma. I have shown the chromosome relation of a giant cell to the normal cells.

The work of Della Valle ('09) and his conclusions in regard to the variability of chromosomes, is so obviously faulty that I shall not consider them here, particularly since Dr. MeClung has discussed his observations and theories at length in a recent paper ('17).

From the above synopses of reported cases of chromosome variations it is evident that the somatic number has been discovered to be different from the spermatogonial number in a few cases and that this is largely due to the breaking up of the major or, what I have termed, the 'type' chromosomes, and in certain cases the same chromosomes are always affected while the others remain intact. If the various workers had measured the chromosomes in the tissues studied we should have more information in regard to the constancy of the chromatin elements.

\section{The metrical study of chromosomes}

Not very much work has been done in the way of measuring chromosomes, and some of the studies along this line have not produced results of value. Among these I think we may place the work of Meek ('12a, '12 b and '15), whose work was exceedingly carefully executed, but whose conclusions had to be retracted eventually as they were too sweeping and based on insufficient data.

Farmer and Digby ('14) found that the "total amount of chromatin substance in the nucleus of each of two types of hybrids known as Primula kewensis is the same. The nuclei of the one form of hybrid contains twice as many chromosomes as 
the nuclei of the other type, but the increase in number is associated with a corresponding diminution in size."

Meves ('11) found a graded series of chromosomes in the salamander $\mathrm{He}$ did not believe that his results showed that pairing exists, but it appears to me that the pairing in his material is as marked as can be expected, considering the possibilities of error through foreshortening and in drawing. This becomes especially evident when the exceedingly long chromosomes of the salamander are recalled.

Robertson ('15) made use of a constant length relation between certain chromosomes to determine the amount of deficiency of chromosomes which had lost a portion of their length, and for the relation of the chromosomes of one type of cells to that of another ('16). The relation of chromosomes in the Orthoptera is evidently as constant as in the case of the two forms I have studied. In a very few measurements of the chromosomes of grasshoppers that I have made, the relationship between pairs is very similar.

I feel certain that many valuable results will be obtained through the measuring of chromosomes and the study of their relation to each other and to the chromosomes of closely related groups. Other applications of these methods have been pointed out in my paper on Oenothera scintillans ('18). In a preliminary survey of the difference in length between the various chromosome pairs of several plants and animals, I have found this relation (between pairs) to be practically constant in any one group and, furthermore, in the few examples thus far examined, it does not vary greatly between widely separated groups. What this means is, of course, impossible to imagine or predict at present. It is exceedingly suggestive, however, of a physical or physiological phenomena which future discoveries may show to be of fundamental importance.

\section{Chromosomes in development}

At the beginning of this paper it was pointed out that an investigation of somatic chromosomes was really a study of the "behavior of chromosomes in development." We have not, I 
fear, progressed very far toward the solution of the problem, but several points have been developed which are of some interest and may form a basis for future work along these lines. The fact that the chromosomes may fragment in the soma has been shown to be meaningless, so far as disturbing the quantity of chromatin is concerned, in both the pig and Oenothera scintillans. A definite and apparently constant relation between the chromosome pairs has been discovered which will be of great value in analysing unusual chromosome conditions, such as fragmentation, multiple chromosomes, and the total loss of parts of chromosomes.

Contrasted to the breaking up of chromosomes we have the fusion of certain elements, as described by McClung ('17), Robertson ('16) and Woolsey ('15) and the loss of a portion of certain chromosomes; Carothers ('13 and '17), Robertson ('15) and Wenrich ('16). In these cases the chromosome phenomena link up closely with the taxonomic peculiarities. With the exception of those cases in which certain chromosomes are deficient, the total length of the chromosomes of the cells where these other phenomena have occurred, is, as expected, the same as in the cases where the chromosomes have not fused. The fusion has come about simply as an end to end union. What these phenomena may mean or how or why they have occurred is as much of a riddle as is the breaking up of chromosomes.

A great mass of unquestionable work on plants and animals has demonstrated that the somatic number is the same as the diploid number of the germ cells. To mention but a few-the studies on the squash bug (Morril, '13), Hoy ('16), those on many of the Oenotheras (Gates '15), the work on the mosquito and the Drosophila (Metz, '14 and '16, Whiting, '17 and Hance, '17) have all irrefutably shown that the two types of cells are alike in chromosome numbers.

What, then, does the fact mean that, on the one hand, we find the somatic chromosomes breaking up, while, on the other, they are constant in form and number? In the case of Oenothera scintillans I have pointed out that this is the most unstable of all the 'mutants' of the Oenothera series and never breeds true. 
It may be that this breaking up of the chromosomes is correlated with the genetic impurity of the plant. The mosquito is without doubt a 'pure' form, and its somatic chromosomes are constant in number. It is difficult to see how Ascaris can be anything but a homozygous form, and yet the somatic chromosomes are highly fragmented. The pig is probably not pure, considering the length of time it has been domesticated, and its somatic chromosomes show a variation in number. The evidence would seem to be rather evenly balanced at present and no conclusions can be safely drawn.

I think, however, that it may be said with some assurance that the present work, and such previous work as is reliable, has tended to show that the chromosome equipment is the same in the various cells of the body, and when fragmentation occurs, it has not been found to affect one tissue more severely than another. In other words, no tissue specificity of the chromosomes has been found.

The fact that the chromosomes of the majority of somatic cells are more or less fragmented would lend some support to the theory that a germ line or cycle exists, the cells composing which are set off at an early period in the history of the individual. While it is not impossible (from the evidence of the present work) that the germ cells may come from already specialized tissues (Hargitt, '17), it seems rather improbable that cells in which the chromosomes, in all probability, have broken up should be able to reform the typical germinal complex." In view of the present work it seems very likely that the anlagen of the future reproductive cells are set off or guarded from the processes which are taking place in the soma, early in the life history of the animal. Otherwise, since, in the majority of somatic cells studied, the chromosomes break up to a greater or lesser degree, we should have to postulate, either that the chromosomes have the power to recombine as stated above, or that certain cells of some tissue do not undergo the changes common to the rest of the soma. The latter supposition is essentially the germ cycle theory. 


\section{The individuality of the chromosomes}

It is not my purpose to enter into a full discussion of the theory of the individuality of chromosomes, as Dr. McClung has thoroughly reviewed this subject in a recent publication ('17). I wish merely to add the proof of the present work to that which has already been done. What follows may have more weight when it is said that I began these investigations with the purpose of disproving the hypothesis and was forced into the ranks of the 'believers' by the unquestionable results obtained.

It has been shown that in the somatic cells the chromosomes which are unfragmented agree in length, chromosome for chromosome, with those of the spermatogonia, and the relation between the pairs is the same. When the chromosomes break up, the fragments behave as entire chromosomes at division, and the total length of all the chromosomes of the cell is the same as in the unfragmented cells and the spermatogonia. The quantity of chromatin is undisturbed. What I have said in regard to the chromosome situation in Oenothera scintillans, in respect to the individuality hypothesis, may well be said for the similar conditions in the pig.

Since no chromatin appears to be lost in the processes that are going on in 0 . seintillans and as the fragments divide as regularly as they did before they were separated it would seem that at least the spirit of the theory of the individuality of chromosomes was maintained. If the theory of the individuality of chromosomes can only recognize a strict morphological continuity then the chromosomes in scintillans lose their individuality through breaking up. If the theory is broader in its scope and admits an individuality not only of whole chromosomes but of the chromatin or chromomeres then the scintillans situation falls within its limits. It is the latter interpretation of the theory that I believe cytologists hold or are tending toward today.

\section{SUMMARY}

\section{Technique}

1. An improved preservation of mammalian tissue has been obtained through the use of Flemming's (strong and weak) solution, to which has been added a little urea and which is 
used at a temperature of four degrees Centigrade. The pieces of tissue fixed must be very small and absolutely fresh (p. 158).

\section{Observations}

2. The number of spermatogonial chromosomes is 40 (p. 162 figs. 1 to 20 ).

3. The reduced or first spermatocyte number of chromosnmes is 20 (p. 164, figs. 21 and 22 ).

4. The somatic chromosomes range in number from 40 to 58-one cell with 74 chromatin bodies has been found (p. 165, figs. 22 to 80 ).

5. The 'extra' chromosomes divide as do the type chromosomes (p. 168, fig. 57).

6 . The variation in number is caused by the fragmentation of certain chromosomes (p. 169).

\section{Analysis of the chromosome conditions}

7. The total length of the chromosomes $(\times 20400)$ of the spermatogonia varies from $118.6 \mathrm{~cm}$. to $177.6 \mathrm{~cm}$; average, $136.9 \mathrm{~cm}$. (p. 172).

8. When the chromosomes are arranged side by side according to length, they form a series which falls very gradually from the long end to the short end of the series (p. 172).

9. In such a series the chromosomes are found to lie in pairs (p. 172).

10. A fairly constant difference in length exists between the pairs (p. 176).

11. The total length of the chromosomes in the somatic cells $(\times 20400)$ ranges from $117 \mathrm{~cm}$. to $176.1 \mathrm{~cm}$., showing these cells to be within the spermatogonial limits (p. 176).

12. No tissue specificity of chromosome behavior has been found (p. 165).

13: The chromosome fragments are very nearly of even length suggesting that the chromosomes lose a portion constantly represented by one or two chromosomes (p. 178). 
14. The conditions found in Oenothera scintillans and the pig agree in practically all details (p. 181).

15. The chromosomes at the long end of the series are the ones that are chiefly concerned in fragmentation (p. 183).

16. Fragmentation does not enter the germ line.

\section{Discussion}

17. Much of the cytological work that has been done on mammals is believed to be faulty due to improper fixation (p. 184).

18. Previous studies on the pig are reviewed and it has been demonstrated that, although only 18 chromosomes were reported, the actual amount of chromatin present is probably the same as found in this investigation. The chromosomes as reported are fused and clumped together in the earlier work; due to poor fixation (p. 185).

19. The various types of chromosome variation (multiples, deficient chromosomes, the loss of chromosomes and fragmentation) that have been studied recently are briefly discussed (pp. 190, 194 and 232).

20. It is pointed out that although many of these peculiarities are closely linked with taxonomic differences, the cause of these variations is still obscure (p. 194).

21. The additional evidence that the present work affords the theory of the individuality of chromosomes is commented upon (p. 196).

\section{Results of the investigation in brief*}

The chromosomes of the soma may fragment but the fragments continue as part of the complex. The total amount of chromatin in the somatic cell in which fragmentation has occurred is the same as in the spermatogonia. There is no fragmentation in the germ cells, and the chromosome complex remains unchanged. 


\section{BIBLIOGRAPHY}

BAchHuBer, L. J. 1916 The behavior of the accessory chromosomes and of the chromatoid body of the rabbit. Biol. Bull., vol. 30 .

Boveri, T. 1899 Die Entwicklung von Ascaris megalocephala. Jena.

Carothers, E. E. 1913 The Mendelian ration in relation to certain Orthopteran chromosomes. Jour. Morph., vol. 24.

1917 The segregation and recombination of homologous chromosomes as found in two genera of Acrididae. Jour. Morph., vol. 28.

Della Valle, P. 1909 L'Organizzazione della cromatina studiata mediante il numero dei cromosomie. Arch. Zool., 4.

Doncaster, L. 1907 Cametogenesis and fertilization in Nematus ribesii. Quart. Journ. Mic. Sc., vol. 51.

Duespera, J. 1906 Sur le nombre des chromosomes chez l'homme. Anat. Anz., vol. 28.

Farmer, J. B. AND DigBy, L. 1914. On dimensions of chromosomes considered in relation to phylogeny. Philos. Trans. Roy. Soc. London (B.). vol. 205.

Farmer, J. B., ANd Moore, J. E. S. 1905 On the maiotic phase (reduction divisions) in animals and plants. Quart. Journ. Micr. Sci., vol. 48.

Flemming. 1898 Ueber die Chromosomenzahl beim Menschen. Anat. Anz., Bd. 14.

Gates, R. R. 1915 The mutation factor in evolution. London.

GuYer, M. F. 1909 Accessory chromosomes in man. Biol. Bull., vol. 19. 1914 A note on the accessory chromosomes of man. Science, N. S., vol. 39 .

HANCE, R. T. 1917 a The somatic chromosomes in the mosquito Culex pipiens. Jour. Morph., vol. 28.

$1917 \mathrm{~b}$ The fixation of mammalian chromosomes. Anat. Rec., vol. 12. $1917 \mathrm{c}$ Studies on a race of paramaccium possessing extra contractile vacuoles. I. Jour. Exp. Zool., vol. 22.

1918 Somatic chromosome variations in the evening primrose, Cenothera scintillans. Genetics.

HARGITT, C. T. 1917 Germ cells of coelenterates. Jour. Morph., vol. 28.

Hoxt, C. M. 1917 Multiple complexes in the alimentary tract of the mosquito. Jour. Morph., vol. 29.

Hor, W. E. 1916 A study of somatic chromosomes. I. Biol. Bull., vol. 31. (A large bibliography on somatic chromosomes and on chromosomes. in general is appended to this paper.)

JoRDAN, H. E. 1911 The spermatogenesis of the opossum (Didelphis virginiana) with special reference to the accessory chromosome and the chondriosomes. Arch. f. Zellf., vol. 7.

1914 The spermatogenesis of the mongoose, and a further comparative study of mammalian spermatogenesis, with special reference to sex chromosomes. Pub. Carn. Inst. Wash., 182.

Lewis, M. R. ANd Robertson, Wy. R. B. 1916 The mitochondria and other structures observed by the tissue culture method in the male germ cells of Chorthippus curtipennis Scudd. Biol. Bull., vol. 30 . 
MeClung, C. E. 1917 The multiple chromosomes of Hesperotettix and Mermeria. Jour. Morph., vol. 29.

My к, C. F. U. 1912 a A metrical analysis of chromosome complexes showing correlation of evolutionary development and the chromatin thread width throughout the animal kingdom. Philos. Trans. Roy. Soc. London (B.), vol. 203.

$1912 \mathrm{~b}$ The correlation of somatic characters and chromatin rod lengths, being a further study of chromosome dimensions. Journ. Linn. Soc. (London), Zoology, vol. 32.

1915 A further study of the mitotic spindle in the spermatocytes of Forficula auricularia. Quart. Journ. Mic. Sc., vol. 61.

Metz, C. W. 1914 Chromosome studies in the diptera. I. Jour. Exp. Zool., vol. 17.

1916 Chromosome studies in the diptera. II. Jour. Exp. Zool., vol. 21.

Meves, F. 1911 Chromosomenlangen bei Salamandra, nebst Bemerkungen zur Individualitätstheorie der Chromosomen. Arch, f. mik. Anat., Bd. 77 .

Montgomery, T. H. 1912 Human spermatogenesis. Journ. Acad. Nat. Sci. Phila., vol. 15.

Moore, J. E. S., AND ARNoLd, E. 1916 On the existence of permanent forms among the chromosomes of the first maiotic division in certain animals. Proc. Roy. Soc. London, vol. 77B.

Nachtsheim, H. 1913 Cytologische Studien über die Geschlechtsbestimmung bei der Hồnigbiene. Arch. f. Zellf., Bd. 11.

RAth, O. vom. 1894 Ueber die Konstanz der Chromosomenzahl bei Tieren. Biol. Centr., Bd. 14.

Robertson, WM. R. B. 1915 Chromosome studies. III. Jour. Morph., vol. 26.

1916 Chromosome studies. I. Jour. Morph., vol. 27.

Schomnferd, H. 1902 La spermatogenese chez le taureau et chez les mammiferes en general. Arch. de Biol. vol. 18.

Seiler, J. 1914 Das Verhalten der Geschlechtschromosomen bei Lepidopteren. Arch. f.: Zellf., Bd. 12.

Stevens, N. M. 1911 Heterochromosomes in the guinea pig. Biol. Bull., vol. 21.

Sutron, W. S. 1902 On the morphology of the chromosome group in Brachystola magna. Biol. Bull., vol. 4.

Wennich, D. H. 1916 The spermatogenesis of Phrynotettix magnus with special reference to synapsis and the individuality of the chromosomes. Bull. of the Museum of Comp. Zool. at Harvard College, vol. 60 .

Whiting, P. W. 1917 The chromosomes of the common house mosquito, Culex pipiens. 'Jour. Morph., vol. 28.

Wieman, H. L. 1913 Chromosomes in man. Am. Jour. Anat., vol. 14. 1917 The chromosomes of the human spermatocytes.'Am. Jour. Anat., vol. 21. 
Winiwarter, H. von 1900 Le corpuscle intermediaire et le nombre des chromosomes du Lapins. Arch. de. Biol., vol. 16.

1912 Etudes sur la spermatogenese humaine. Arch. de Biol., vol. 27.

Winiwarter and SaINmont 1909 Nouvelles recherches sur l'ovogenese et l'organogenese de l'ovaire de mammiferes (chat). Arch. de Biol., vol. 24.

WodsedaleK, J. E. 1913 Accessory chromosomes in the pig. Science, N. S., vol. 38 .

1913 Spermatogenesis of the pig with special reference to the accessory chromosomes. Biol. Bull., vol. 25.

1914 Spermatogenesis of the horse with special reference to the accessory chromosome and the chromotoid body. Biol. Bull., vol. 27. 1916 Causes of sterility in the mule. Biol. Bull., vol. 30.

Woolsey, C. I. 1915 Linkage of chromosomes correlated with reduction in numbers among species of a genus, also within a speces of Locustidae. Biol. Bull., vol. 28.

Yocum, H. B. 1917 Some phases of spermatogenesis in the mouse. Univ. of Cal. Pub. in Zool., vol. 16. 
Figures 1 to 88 were drawn with the aid of a camera lucida using a Zeiss 1.5 $\mathrm{mm}$. apochromatic objective and a $12 \times$ compensating ocular. This gave a magnification at table level of $3400 \times$. The pencil drawings were then enlarged to twice the original size with an aceurate pantograph. They are reproduced two-fifths off at a magnification of $4080 \times$. In all cases where chromosomes are believed to have divided the mates are connected with a bar except when the separation appears as only a slight slit.

Figs 1 to 80 have been drawn from material fixed in Flemming's strong solution. See page 217 for complexes found in material preserved in Flemming's weak solution.

\section{PLATE 1}

FXILLANATION OF FIGURES

Spermatogonia from three breeds of pigs

\begin{tabular}{c|l|l|l}
\hline FIGURE number & \multicolumn{1}{|c|}{ stage } & Breed & ANimal \\
\hline 1 and 2 & Prophase & Jersey red & a \\
3 & Metaphase & Berkshire & f \\
4 and 5 & Metaphase & Berkshire & f \\
6,7 and 8 & Metaphase & Jersey red & a \\
9 & Late prophase & Jersey red & c \\
10 & Metaphase & Jersey red & a \\
11 and 12 & Metaphase & Poland China & \\
\hline
\end{tabular}



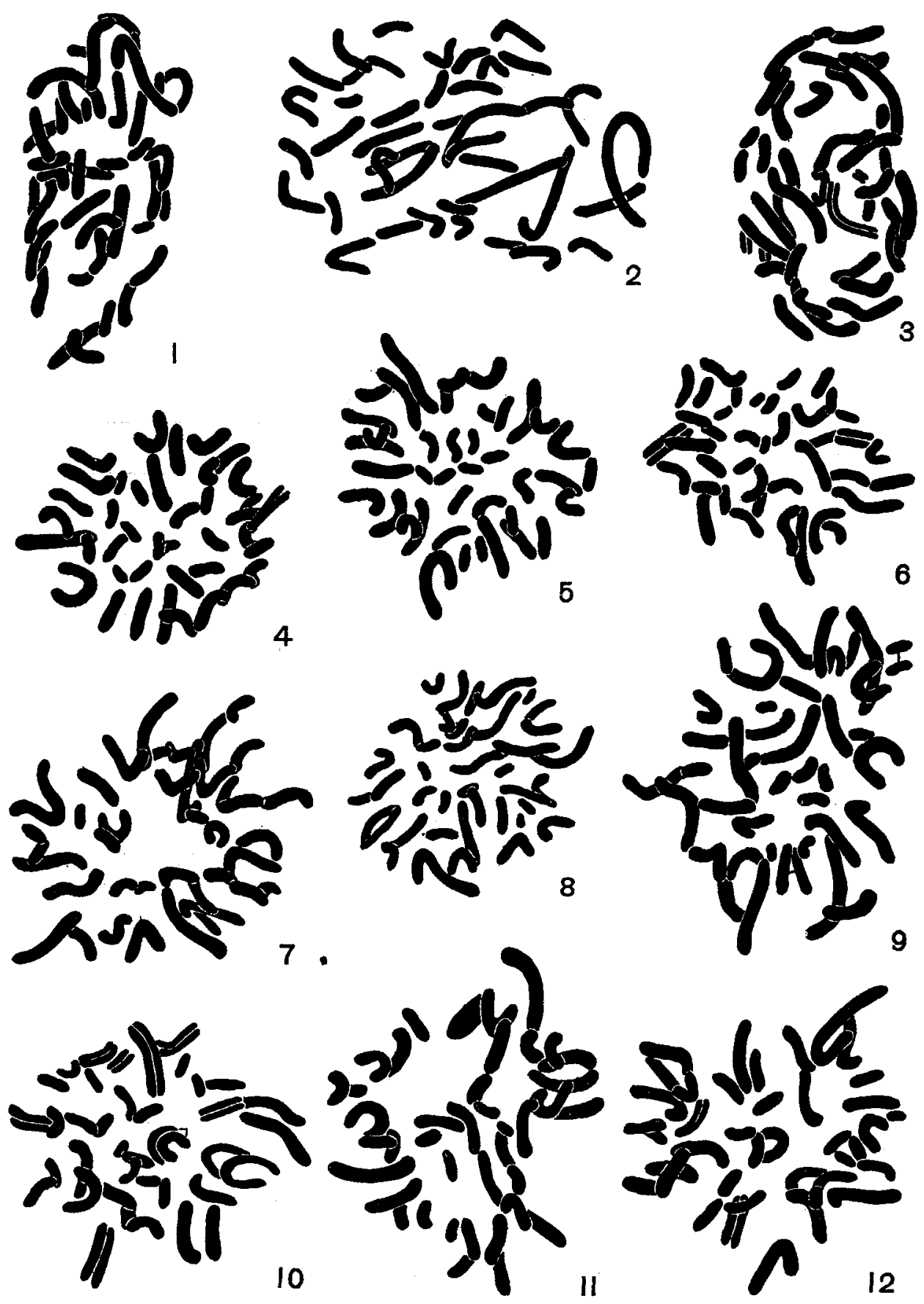
FLATE 2

EXPLANATION OF FIGURES

Spermatogonia and first spermatocytes

\begin{tabular}{|c|c|c|c|c|}
\hline FLGURE NUMBER & STAGE & BREED & ANIMAL & NUMBER OF CHROMOSOMES \\
\hline 13 & Metaphase & Berkshire & $\mathrm{f}$ & 40 \\
\hline 14 & $\begin{array}{l}\text { Giant cell } \\
\text { spermato- } \\
\text { gonium }\end{array}$ & Berkshire & $\mathrm{f}$ & 74 or more \\
\hline 15 & Metaphase & Berkshire & $\hat{\mathrm{f}}$ & 40 \\
\hline 16 & Anaphase & Berkshire & f & $\begin{array}{l}40 \text { at pole to the left in- } \\
\text { cluding chromosome } \\
\text { lying between poles. } \\
\text { Poles displaced in } \\
\text { drawing }\end{array}$ \\
\hline $17,18,19$ and 20 & Metaphase & Jersey red & a & 40 \\
\hline 21 and 22 & $\begin{array}{l}\text { Spermatocyte } \\
\text { I. Meta- } \\
\text { phase }\end{array}$ & Jersey red & a & 20 \\
\hline
\end{tabular}




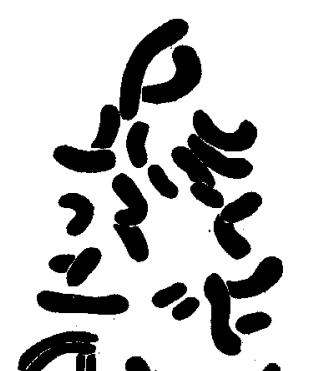

ROBERT T. HANCE
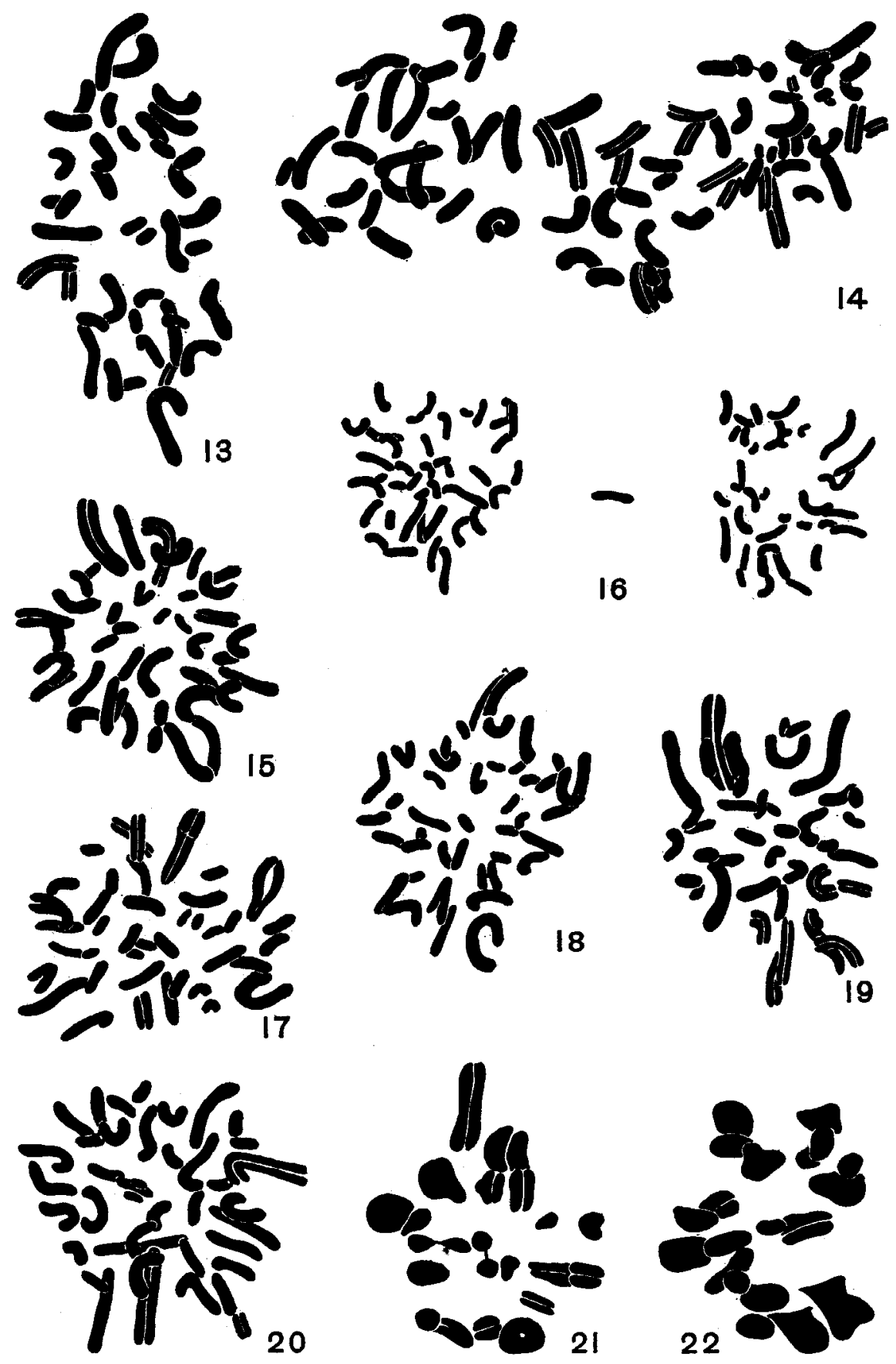


\section{PLATE 3}

EXPLANATION OF FIGURES

Polar views of metaphase stages from the brain of a $10 \mathrm{~mm}$. pig embryo

\begin{tabular}{c|c}
\hline FIG URE NUMBER & NUMBer of CHRomosomes \\
\hline 23 & 40 \\
24 & 42 \\
25 & 43 \\
26 & 46 \\
27 & 48 \\
28 & 47 \\
29 & 49 \\
30 & 50 \\
31 & 50 \\
32 & 52 \\
33 & 54 \\
34 & 54 \\
\hline
\end{tabular}


THE DIPLOID CHROMOSOME COMPLEXES OF THE PIG PLATE 3
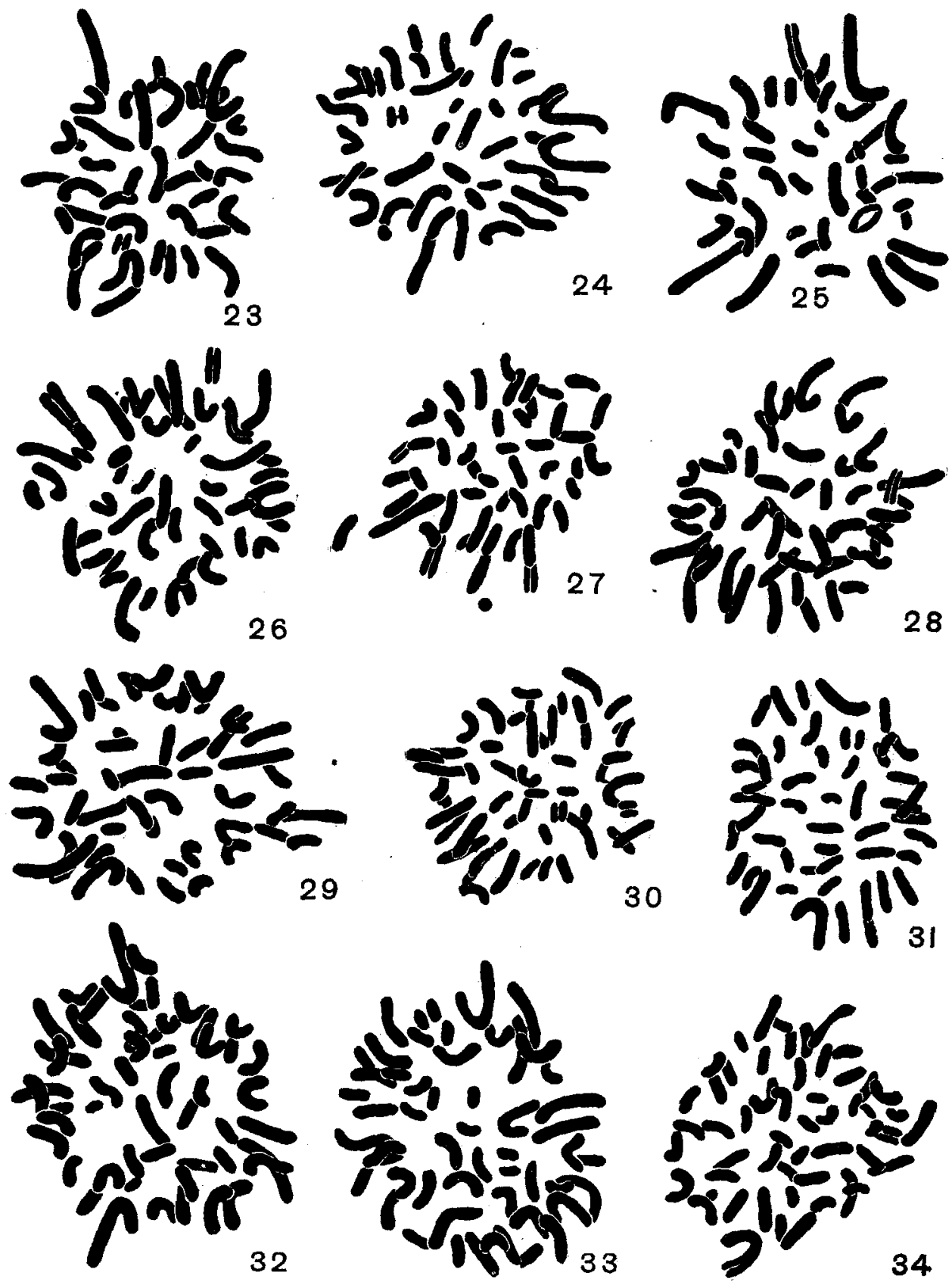
PLATE 4

EXPLANATION OF FIGURES

Polar views of metaphase stages, from blood cells of pig embryos

35 to 45 From a $10 \mathrm{~mm}$. pig embryo

46 From a $15 \mathrm{~mm}$. pig embryo

\begin{tabular}{|c|c|c|}
\hline FIGURE NUMBER & $\begin{array}{l}\text { NUMBER OF } \\
\text { CHROMOSOMES }\end{array}$ & REMARKS \\
\hline 35 & 41 & Count not certain \\
\hline 36 & 41 & $\begin{array}{l}\text { Count not certain-note thin section in chro- } \\
\text { mosome to left of number. May be possible } \\
\text { point of fragmentation }\end{array}$ \\
\hline 37 & 42 & \\
\hline 38 & 43 & \\
\hline 39 & 44 & \\
\hline 40 & 45 & \\
\hline 41 & 47 & \\
\hline 42 & 47 & \\
\hline 43 & 49 & \\
\hline 44 & 50 & \\
\hline 45 & 55 & \\
\hline 46 & 73 & $\begin{array}{l}\text { Very uncertain-the number of chromosomes is } \\
\text { at least as many as indicated }\end{array}$ \\
\hline
\end{tabular}



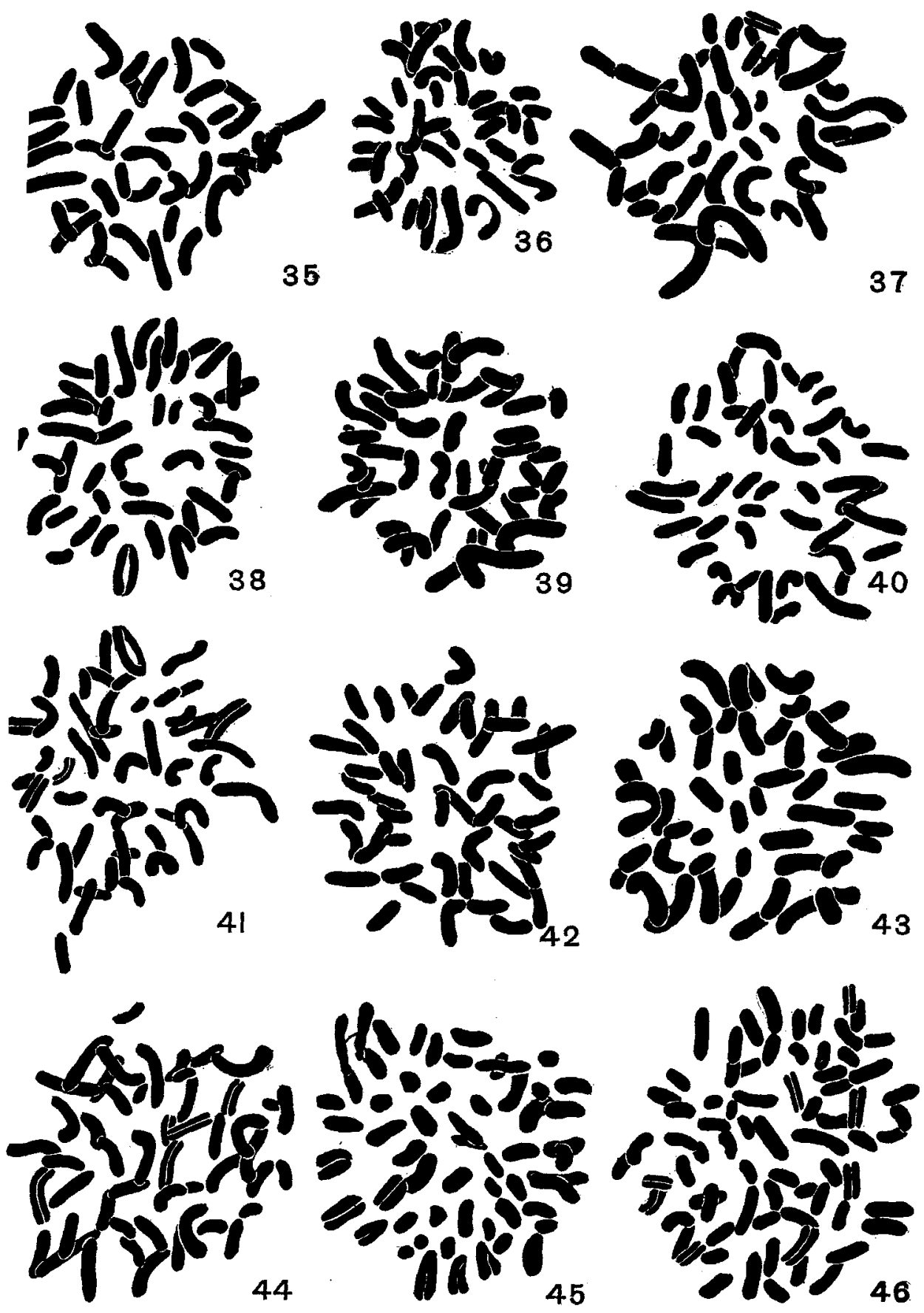
PLATE 5

EXPLANATION OF FIGURES

Polar view from metaphase stages from connective tissue cells

52 In late prophase

\begin{tabular}{c|c|c}
\hline Figure NumBer & $\begin{array}{c}\text { NUMBer of } \\
\text { Cirromosomes }\end{array}$ & Remarks \\
\hline 47 & 42 & Count not certain-probably higher \\
48 & 43 & \\
50 & 43 & \\
51 & 45 & Count not certain \\
52 & 47 & \\
53 & 45 & \\
54 & 59 & \\
55 & 50 & Count not certain \\
56 & 53 & Count not certain \\
\hline
\end{tabular}

57 The upper pole shows 43 chromosomes. Though the count is not certain there are at least as many chromosomes as figured. Since there are this number it is evident that the fragments must divide. The lower pole shows but 36 chromosomes but it was turned at an angle which made accurate drawing impossible. 

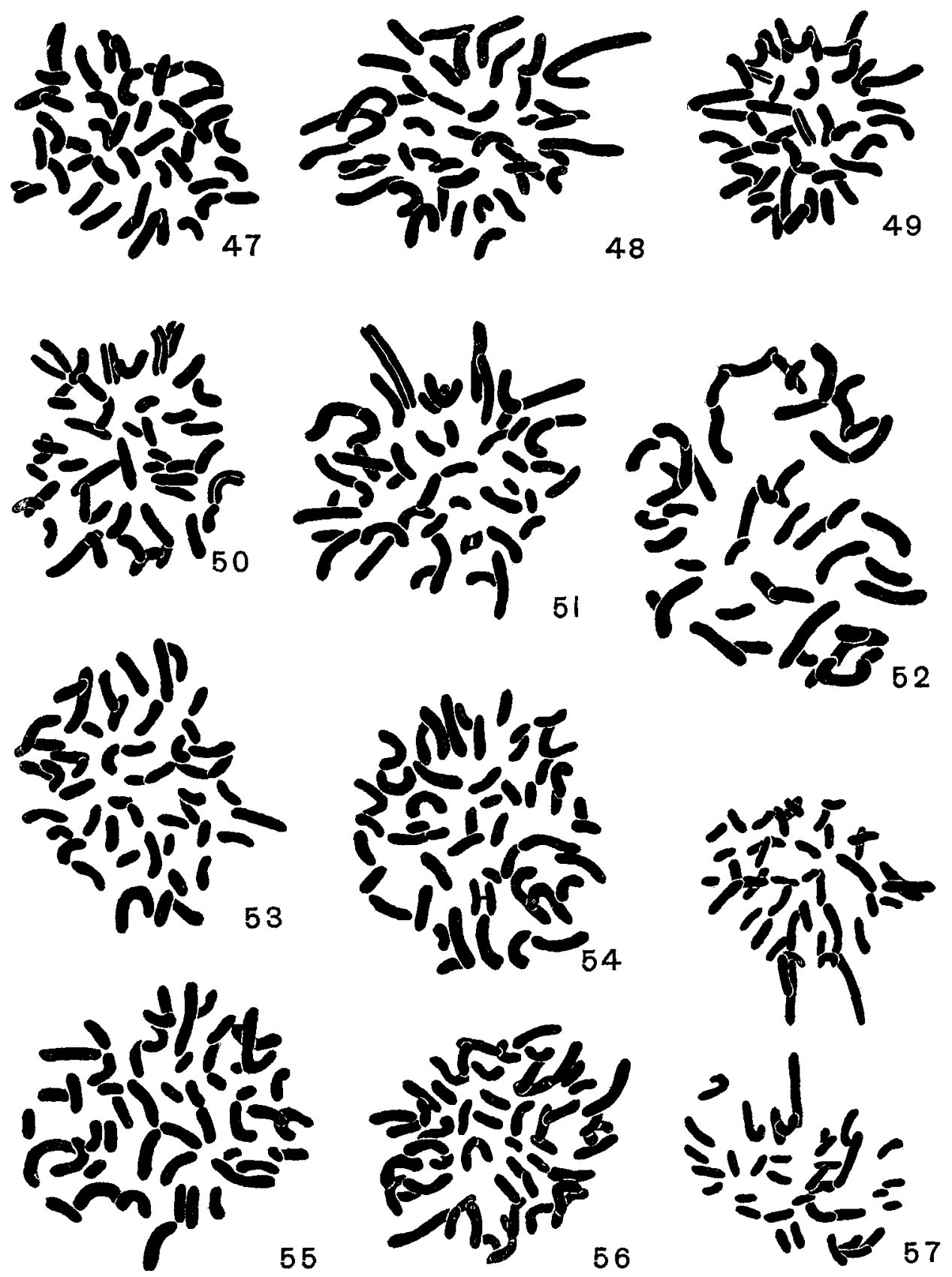
PLATE 6

EXPLANATION OF FIGURES

Polar views of metaphase stages from the cells of various tissues From a $8 \mathrm{~mm}$. pig embryo.

\begin{tabular}{c|c|c|c}
\hline FigURE NUMBER & Tissue & $\begin{array}{c}\text { NUMBER OF } \\
\text { CHROMOSOMES }\end{array}$ & REMARKs \\
\hline 58 & Diaphragm & 44 & Count uncertain \\
59 & Limb bud & 45 & \\
60 & Limb bud & 48 & \\
61 & Limb bud & 49 & \\
62 & Limb bud & 50 & \\
63 & Limb bud & 52 & \\
64 & Myotome & 44 & \\
65 & Myotome & 41 & \\
66 & Heart & 43 & \\
67 & Myotome & 54 & Probably a giant cell \\
68 & Mesoderm &
\end{tabular}



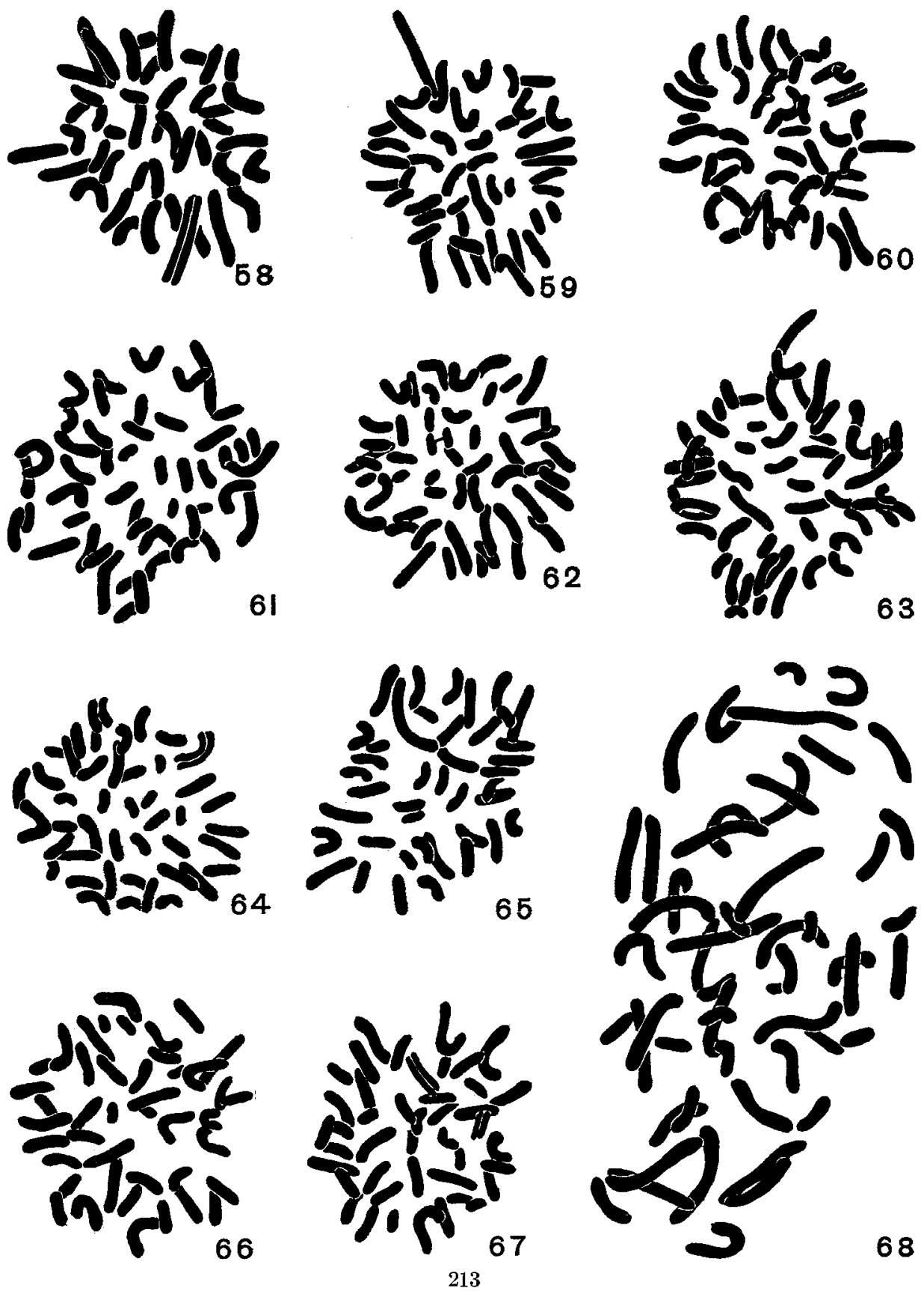
PLATE 7

EXPLANATION OF FIGURES

Polar views of metaphases in cells of various tissues 69 and 70 From $15 \mathrm{~mm}$. pig embryo. Other figures from $8 \mathrm{~mm}$. pig ${ }^{7}$ embryo.

\begin{tabular}{c|l|c|c}
\hline FIGURE NUMBER & \multicolumn{1}{|c|}{ TISSUE } & $\begin{array}{c}\text { NUMBER OF } \\
\text { CH ROMOSOMES }\end{array}$ & REMARK8 \\
\cline { 2 - 4 } 69 & Amnion & 40 \\
70 & Amnion & 41 & \\
71 & Amnion & 50 & \\
72 & Liver & 47 & \\
73 & Liver & 53 & \\
74 & Liver & 45 & \\
75 & Wolffian body & 41 & \\
76 & Wolffian body & 48 & Count uncertain \\
77 & Wolffian body & 55 & \\
78 & Lung & 53 & \\
79 & Optic cup & 46 & \\
80 & Umbilicus &
\end{tabular}




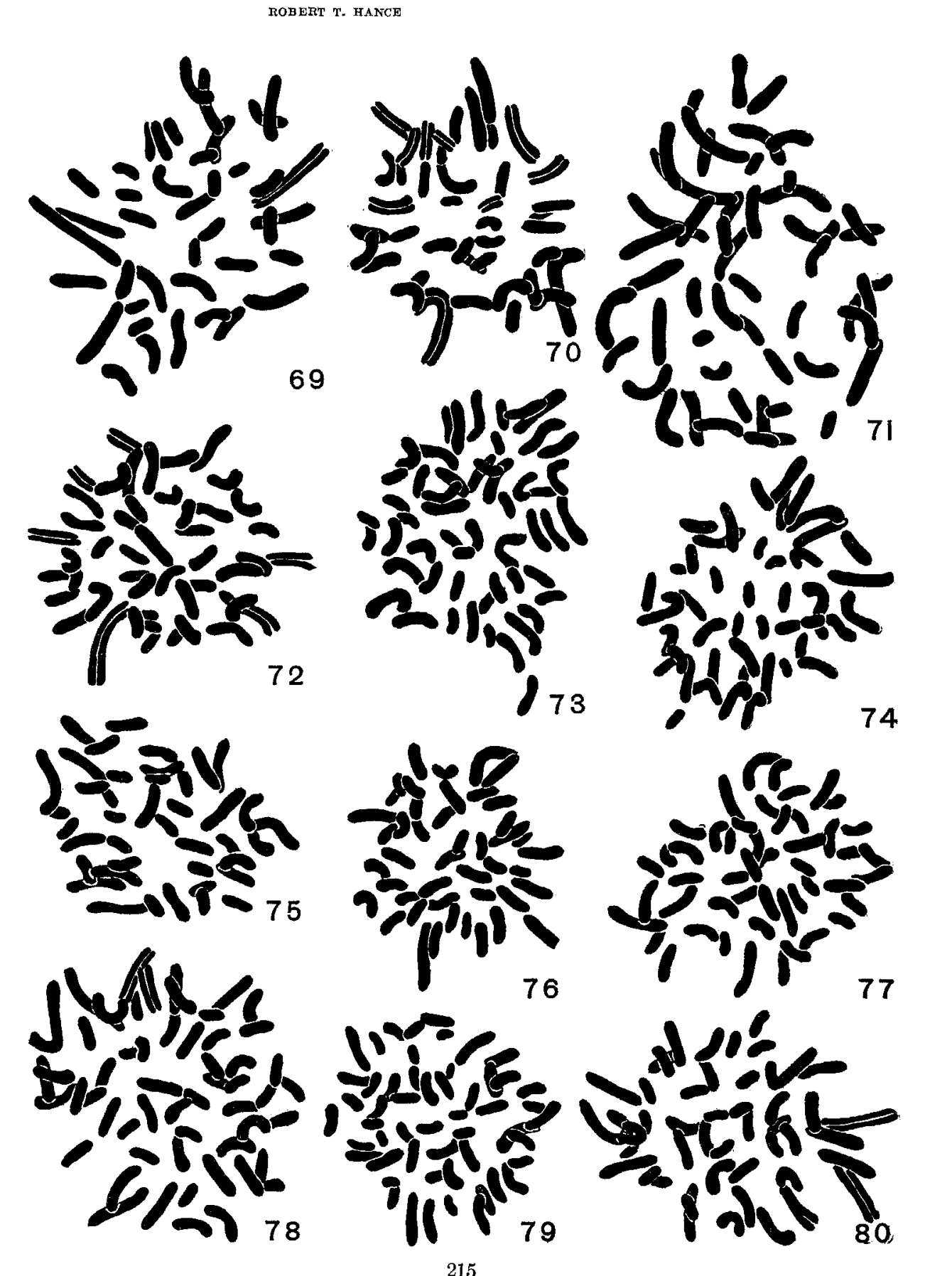


PLATE 8

EXPLANATION OF FIGURES

$81,82,84,85$ and 88 Drawn from amnion fixed in Flemming's weak solution. 83, 86 and 87 Drawn from amnion killed in Flemming's strong solution.

\begin{tabular}{c|c}
\hline MIGURE NUMBER & NUMBER OF CHROMOSOMEs \\
\hline 81 & 40 \\
82 & 53 \\
83 & 40 \\
85 & 44 \\
\hline
\end{tabular}

$84,86,87$ and 88 Show the structure of the chromosomes as they pass the poles and are discussed in the text on page 163 . 

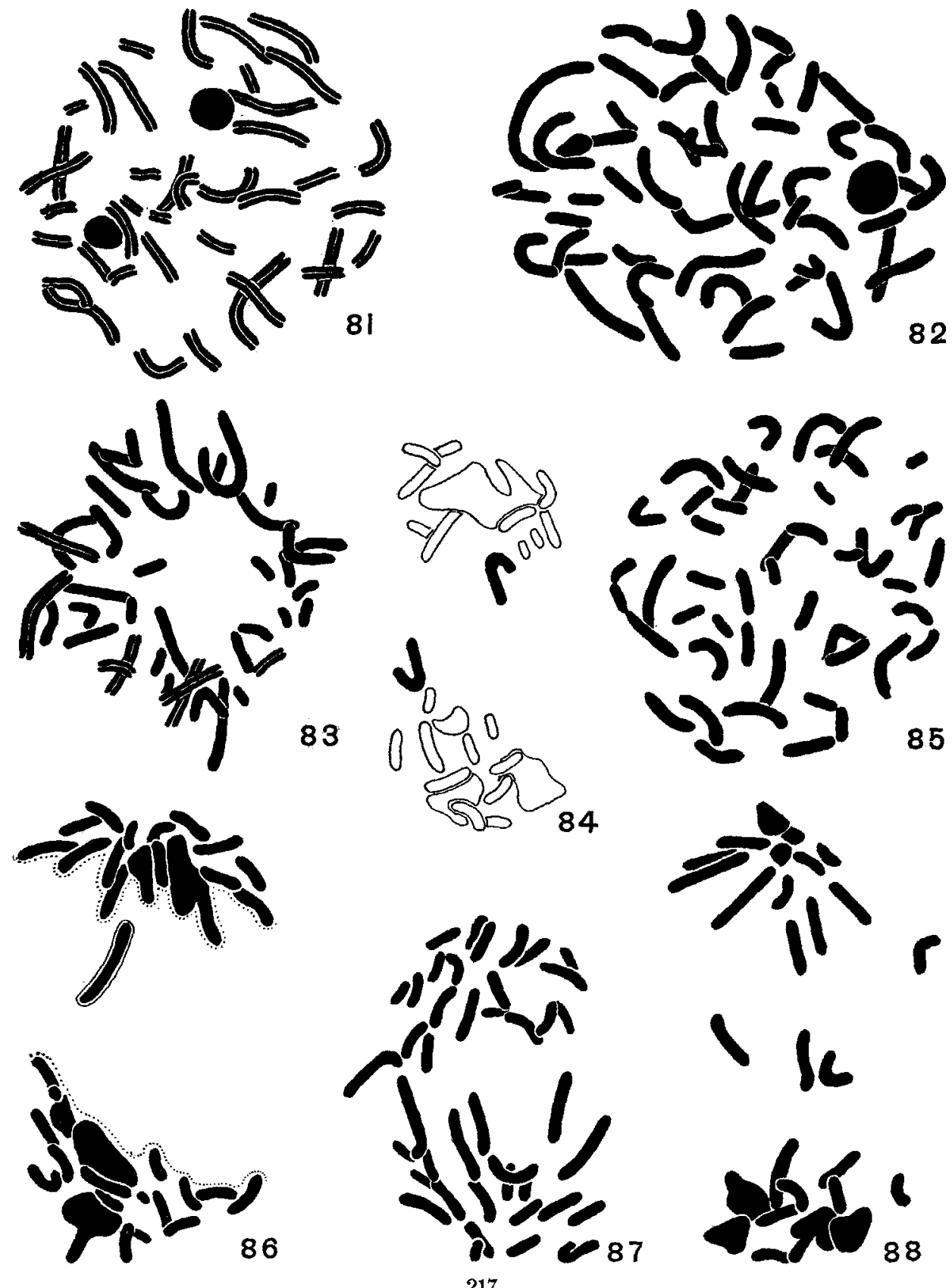

85
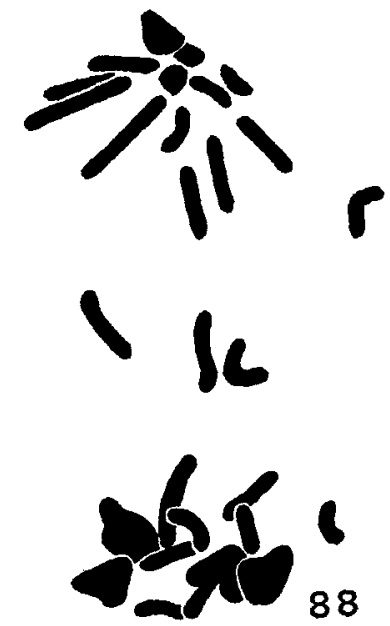


\section{PLATE 9}

EXPLANATION OF FIGURES

In preparing these photomicrographs a Zeiss $1.5 \mathrm{~mm}$. apochromatic objective and a $4 \mathrm{X}$ compensating ocular were used. The magnification at the level of the plate was about 1000 diameters. Seeds Process Plates were used. The photographs were made with the aid of artificial illumination. The photomierographs appear in reproduction at the original magnification.

\begin{tabular}{c|l|c|c}
\hline FIGURE NUMBER & \multicolumn{1}{|c|}{ TISSUE } & $\begin{array}{c}\text { NUMBER OF } \\
\text { CHROMOSOMES }\end{array}$ & $\begin{array}{c}\text { SAME CELL AE FIGURE } \\
\text { NUMBER }\end{array}$ \\
\hline 89 & Amnion & & \\
90 & Amnion & & \\
91 & Amnion & 53 & \\
92 & Amnion & 45 & \\
93 & Amnion & 50 & \\
95 & Amnion & 50 & 4 and 5 \\
96 and 97 & Spermatogonia & 40 & 24 \\
98 & Brain & 42 & 45 \\
99 & Blood & 55 & \\
\hline
\end{tabular}

89, 92, 93 and 95 Fixed in Flemming's weak solution.

90, 91, and 96 to 99 Killed in Flemming's strong solution.

94 Illustrates the results obtained in poor fixation. This is a photograph of a group of poorly fixed spermatogonial cells in the testes of a pig. 

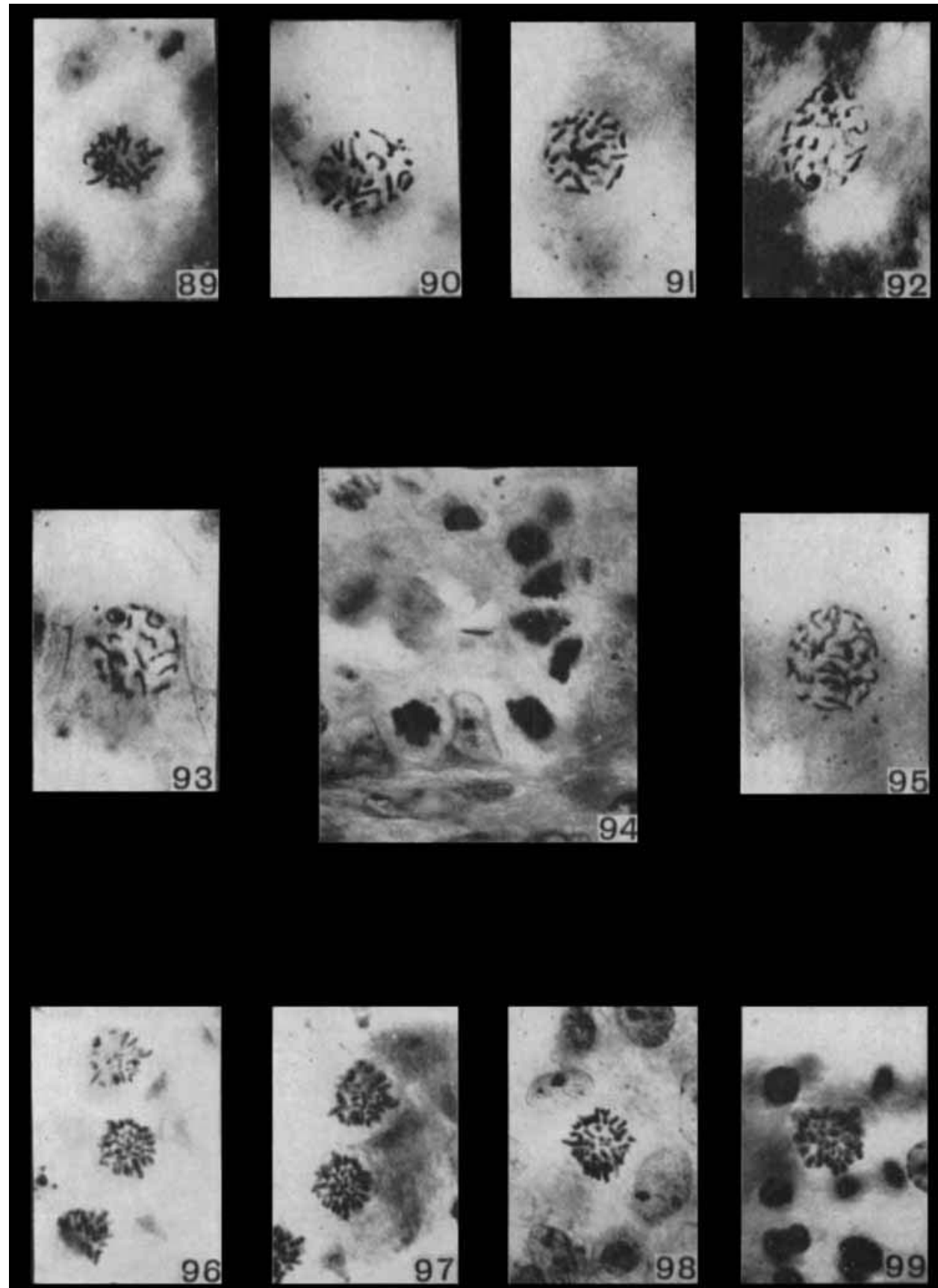
PLATE 10

EXPLANATION OF FIGURES

See table giving the length in millimeters of the chromosomes.

The chromosomes were enlarged to 20400 diameters before being measured. Under 'figure number' is given the number of the complex as it appears on previous plates. The number of the individual chromosomes as they appear on plate 10 is given in the columns to the left.

\begin{tabular}{|c|c|c|c|c|c|c|c|c|c|c|c|c|}
\hline $\begin{array}{c}\text { FIGURE NUM- } \\
\text { BER }\end{array}$ & 5 & 23 & & 31 & & 70 & 67 & 63 & 45 & 56 & 78 & 73 \\
\hline Tissue... & 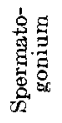 & 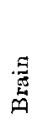 & 志 & 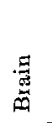 & 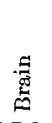 & 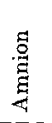 & 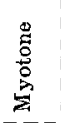 & 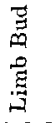 & $\frac{\overline{8}}{x}$ & 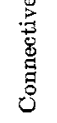 & 节 & 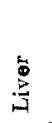 \\
\hline Row Number. & 1 & 2 & 3 & 4 & 5 & 6 & 7 & 8 & 9 & 10 & 11 & 12 \\
\hline 1 & 70 & 76 & 65 & 49 & 55 & 83 & 54 & 52 & 44 & 52 & 68 & 50 \\
\hline 2 & 67 & 58 & 47 & 35 & 53 & 75 & 45 & 47 & 39 & 50 & 65 & 47 \\
\hline 3 & 56 & 55 & 46 & 35 & 43 & 50 & 43 & 46 & 36 & 46 & 55 & 46 \\
\hline 4 & 50 & 52 & 40 & 35 & 40 & 48 & 40 & 46 & 33 & 45 & 49 & 45 \\
\hline 5 & 49 & 49 & 40 & 30 & 38 & 45 & 40 & 44 & 32 & 44 & 45 & 43 \\
\hline 6 & 46 & 49 & 38 & 29 & 38 & 42 & 39 & 41 & 32 & 40 & 43 & 42 \\
\hline 7 & 46 & 46 & 37 & 29 & 33 & 40 & 38 & 40 & 11 & 38 & 43 & 41 \\
\hline 8 & 45 & 45 & 36 & 29 & 32 & 39 & 37 & 40 & 31 & 38 & 42 & 41 \\
\hline 9 & 42 & 43 & 34 & 29 & 31 & 37 & 35 & 39 & 30 & 38 & 40 & 39 \\
\hline 10 & 41 & 43 & 34 & 27 & 31 & 35 & 36 & 38 & 30 & 37 & 40 & 38 \\
\hline 11 & 40 & 43 & 34 & 27 & 30 & 35 & 34 & 37 & 29 & 35 & 38 & 37 \\
\hline 12 & 40 & 43 & 34 & 26 & 30 & 34 & 33 & 36 & 29 & 35 & 38 & 37 \\
\hline 13 & 36 & 40 & 33 & 26 & 30 & 34 & 31 & 35 & 29 & 35 & 37 & 36 \\
\hline 14 & 35 & 40 & 33 & 26 & 30 & 32 & 30 & 35 & 28 & 33 & 37 & 35 \\
\hline 15 & 35 & 40 & 31 & 26 & 30 & 32 & 30 & 34 & 28 & 34 & 37 & 34 \\
\hline 16 & 32 & 39 & 31 & 26 & 29 & 31 & 30 & 33 & 28 & 34 & 35 & 34 \\
\hline 17 & 31 & 39 & 30 & 25 & 28 & 31 & 30 & 33 & 28 & 33 & 35 & 34 \\
\hline 18 & 31 & 39 & 30 & 25 & 28 & 31 & 29 & 33 & 27 & 33 & 35 & 34 \\
\hline 19 & 31 & 39 & 28 & 25 & 28 & 30 & 28 & 32 & 27 & 32 & 34 & 34 \\
\hline 20 & 31 & 38 & 28 & 25 & 27 & 30 & 27 & 32 & 27 & 31 & 33 & 34 \\
\hline 21 & 30 & 38 & 28 & 24 & 27 & 30 & 27 & 31 & 26 & 31 & 33 & 32 \\
\hline 22 & 30 & 33 & 28 & 24 & 27 & 29 & 26 & 30 & 26 & 30 & 33 & 32 \\
\hline 23 & 30 & 33 & 26 & 24 & 26 & 28 & 26 & 30 & 25 & 30 & 33 & 32 \\
\hline 24 & 30 & 30 & 26 & 23 & 26 & 28 & 26 & 29 & 25 & 30 & 33 & 31 \\
\hline 25 & 30 & 29 & 25 & 23 & 26 & 27 & 25 & 28 & 25 & 29 & 32 & 31 \\
\hline 26 & 28 & 28 & 25 & 22 & 25 & 26 & 25 & 28 & 25 & 28 & 31 & 31 \\
\hline 27 & 28 & 28 & 24 & 22 & 25 & 26 & 25 & 28 & 25 & 28 & 30 & 31 \\
\hline 28 & 28 & 28 & 23 & 22 & 25 & 26 & 25 & 27 & 25 & 27 & 30 & 29 \\
\hline 29 & 23 & 27 & 23 & 22 & 25 & 24 & 24 & 27 & 25 & 27 & 30 & 28 \\
\hline 30 & 21 & 26 & 21 & 22 & 25 & 23 & 24 & 26 & 24 & 26 & 30 & 27 \\
\hline 31 & 21 & 25 & 21 & 20 & 23 & 23 & 23 & 26 & 24 & 25 & 30 & 26 \\
\hline 32 & 21 & 25 & 21 & 20 & 23 & 23 & 23 & 26 & 24 & 25 & 29 & 26 \\
\hline 33 & 20 & 23 & 21 & 20 & 22 & 22 & 23 & 26 & 23 & 25 & 28 & 25 \\
\hline
\end{tabular}

(Continued on page 222) 


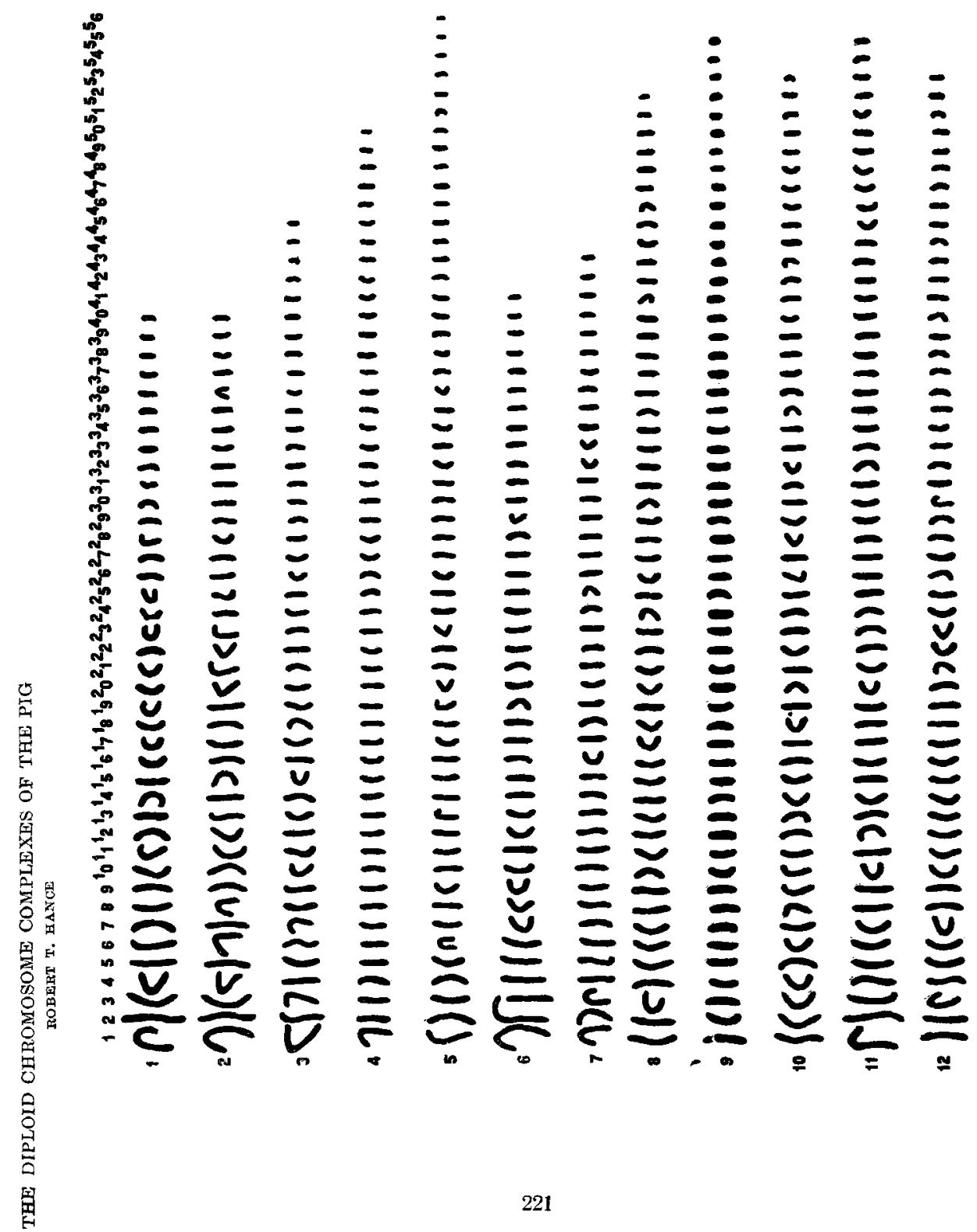




\begin{tabular}{|c|c|c|c|c|c|c|c|c|c|c|c|c|}
\hline \multicolumn{13}{|c|}{ (Continued from page 220) } \\
\hline $\begin{array}{l}\text { FIGUIRE NUM- } \\
\text { BER }\end{array}$ & 5 & 23 & & 31 & & 70 & 67 & 63 & 45 & 56 & 78 & 73 \\
\hline Tissuj ... & 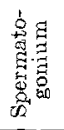 & 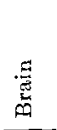 & 苞 & 超 & 灵 & 总 & 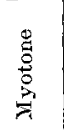 & 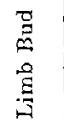 & $\begin{array}{l}\overrightarrow{0} \\
\ddot{g}\end{array}$ & 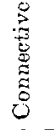 & 照 & 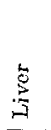 \\
\hline Row Number. & 1 & 2 & 3 & 4 & 5 & 6 & 7 & 8 & 9 & 10 & 11 & 12 \\
\hline 34 & 20 & 23 & 20 & 20 & 22 & 22 & 22 & 25 & 23 & 25 & 27 & 24 \\
\hline 35 & 19 & 23 & 18 & 20 & 22 & 21 & 21 & 25 & 22 & 24 & 27 & 24 \\
\hline 36 & 19 & 23 & 18 & 20 & 21 & 20 & 20 & 25 & 22 & 24 & 27 & 24 \\
\hline 37 & 19 & 22 & 18 & 19 & 20 & 19 & 20 & 23 & 21 & 23 & 27 & 24 \\
\hline 38 & 17 & 20 & 18 & 19 & 20 & 18 & 20 & 23 & 20 & 23 & 26 & 23 \\
\hline 39 & 16 & 20 & 18 & 19 & 19 & 17 & 18 & 23 & 20 & 23 & 26 & 23 \\
\hline 40 & 15 & 18 & 17 & 19 & 19 & 15 & 18 & 22 & 20 & 22 & 25 & 23 \\
\hline 41 & & & 17 & 18 & 19 & 12 & 17 & 22 & 19 & 22 & 25 & 23 \\
\hline 42 & & & 16 & 18 & 19 & & 16 & 21 & 19 & 22 & 24 & 22 \\
\hline 43 & & & 14 & 18 & 19 & & 14 & 21 & 17 & 22 & 24 & 22 \\
\hline 44 & & & 13 & 17 & 18 & & & 21 & 15 & 22 & 23 & 21 \\
\hline 45 & & & 13 & 17 & 18 & & & 21 & 15 & 21 & 23 & 21 \\
\hline 46 & & & & 17 & 18 & & & 19 & 15 & 21 & 23 & 20 \\
\hline 47 & & & & 17 & 18 & & & 19 & 15 & 20 & 23 & 20 \\
\hline 48 & & & & 16 & 16 & & & 19 & 14 & 17 & 22 & 20 \\
\hline 49 & & & & 14 & 16 & & & 19 & 14 & 17 & 22 & 19 \\
\hline 50 & & & & 10 & 15 & & & 19 & 14 & 17 & 21 & 18 \\
\hline 51 & & & & & 15 & & & 15 & 13 & 17 & 21 & 18 \\
\hline 52 & & & & & 14 & & & 12 & 13 & 16 & 20 & 17 \\
\hline 53 & & & & & 14 & & & & 12 & 12 & 18 & 16 \\
\hline 54 & & & & & 12 & & & & 12 & & 18 & \\
\hline 55 & & & & & 10 & & & & 11 & & 17 & \\
\hline 56 & & & & & 9 & & & & & & & \\
\hline
\end{tabular}

